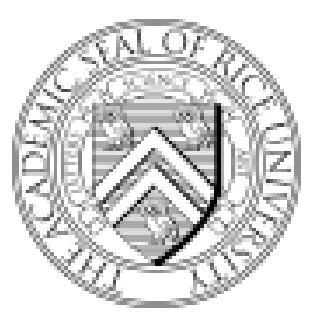

The James A. BAKer III InSTITUTe for Public Policy RICE UNIVERSITY

\title{
ShOUld CAPITAL InCOME BE SUbJECT TO CONSUMPTION-BASED TAXATION?
}

BY

GEORGE R. ZODROW

PROFESSOR OF ECONOMICS AND RICE SCHOLAR TAX AND EXPENDITURE POLICY PROGRAM JAMES A. BAKER III INSTITUTE FOR PUBLIC POLICY RICE UNIVERSITY

APRIL 2006 


\section{Should Capital Income Be Subject to Consumption-Based Taxation?}

THESE PAPERS WERE WRITTEN BY A RESEARCHER (OR RESEARCHERS) W HO PARTICIPATED IN A BAKER INSTITUTE RESEARCH PROJECT. WHEREVER FEASIBLE, THESE PAPERS ARE REVIEWED BY OUTSIDE EXPERTS BEFORE THEY ARE RELEASED. HOWEVER, THE RESEARCH AND VIEWS EXPRESSED IN THESE PAPERS ARE THOSE OF THE INDIVIDUAL RESEARCHER(S), AND DO NOT NECESSARILY REPRESENT THE VIEWS OF THE JAMES A. BAKER III INSTITUTE FOR PUBLIC POLICY.

THIS PAPER WAS PREPARED FOR A CONFERENCE ON "TAXING CAPITAL INCOME" SPONSORED BY THE TAX POLICY CENTER, THE AMERICAN TAX POLICY INSTITUTE, AND TAX ANALYSTS AND HELD AT THE B ROOKINGS INSTITUTION, SEPTEMBER 23, 2005. A REVISED VERSION OF THIS PAPER IS FORTHCOMING IN TAXING CAPITAL INCOME, EDITED BY HENRY J. AARON, LEN BURMAN AND C. EUGENE STEUERLE AND PUBLISHED BY THE URBAN INSTITUTE PRESS. THE AUTHOR WOULD LIKE TO THANK ALAN AUERBACH, LEN BURMAN, JOHN DIAMOND AND JOEL SLEMROD FOR HELPFUL COMMENTS, AND KEVIN GRAHMANN AND ATHIPHAT MUTHITACHAROEN FOR OUTSTANDING RESEARCH ASSISTANCE.

C 2006 BY THE JAMES A. BAKER III INSTITUTE FOR PUbliC POLICY OF RICE UNIVERSITY

THIS MATERIAL MAY BE QUOTED OR REPRODUCED WITHOUT PRIOR PERMISSION, PROVIDED APPROPRIATE CREDIT IS GIVEN TO THE AUTHOR AND THE JAMES A. BAKER III INSTITUTE FOR PUBLIC POLICY. 


\section{Introduction}

Fundamental tax reform is once again high on the policy agenda in the United States, highlighted by the report of the President's Advisory Panel on Federal Tax Reform. Recent discussions have focused on two familiar alternative routes for reform. The first is incremental improvements in the existing income tax (Gale, 2005); these often involve integration of the individual and business income taxes along the lines discussed in Treasury (1992), including the proposal for a "Comprehensive Business Income Tax" (CBIT) which would tax deductions for interest expense at the business level while largely eliminating individual level taxation of capital income. The second approach reflects a conviction that such reforms, like the celebrated Tax Reform Act of 1986, are not sufficiently "fundamental," and advocates replacement of the income tax system with a consumption-based tax; alternative approaches to achieving this goal include an expenditure tax system, the Hall-Rabushka Flat Tax, the Bradford X-Tax, a national retail sales tax, and a value-added tax. ${ }^{1}$ The primary difference between the income and consumption tax

1 See the articles in Boskin (1996) for a discussion of the details of the various consumption tax options, which are also analyzed in Zodrow and McLure (1991) and Gillis, Mieszkowski and Zodrow (1996); recent discussions of the many issues raised by consumption tax reforms are found in the articles in Aaron and Gale (1996), Zodrow and Mieszkowski (2002a) and Auerbach and Hassett (2005a). A brief characterization of some of the most popular generic approaches is as follows.

An expenditure tax, such as that proposed by Aaron and Galper (1985), would allow unlimited deductions for all savings and full taxation of all withdrawals, with loans treated on a cash flow basis (proceeds taxable and repayments of principal and interest deductible); it would be accompanied by a consumption-based business tax that would allow expensing of all business-related purchases, including capital equipment and inventories, and cash flow treatment of loans. The Flat Tax, designed by Hall and Rabushka $(1983,1995)$ would ignore all financial transactions, taxing businesses on their real transactions on a cash flow basis with a deduction for labor compensation, which would then be taxed at a flat rate at the individual level subject to a standard deduction and personal exemptions. The Flat Tax is often described as a "prepaid" consumption tax in that the absence of a deduction for saving implies that the tax on future consumption financed with such saving has been prepaid; by comparison, the expenditure tax is a "postpaid" consumption tax in that tax is not due on consumption financed with saving until consumption actually occurs. The Bradford $(1986,1987)$ X-Tax is a version of the Flat Tax, modified to include progressive tax rates at the individual level. A national retail sales tax would tax final consumption at the retail level (Burton and Mastromarco, 1997), while a value-added tax would collect the same tax revenue as a sales tax but at the various stages in the production process (McLure 1987).

Variants of these proposals have also been constructed, including the income/VAT system advocated by Graetz (2005), the hybrid prepaid/postpaid progressive consumption tax proposed by McLure and Zodrow (1996), the "two-tier VAT" discussed by Weisbach (2003) which combines a credit-invoice destination-based VAT with an Xtax type individual tax, the "allowance for corporate equity" proposal (which allows a deduction for depreciation supplemented by a deduction equal to the product of remaining basis and the interest rate) advocated by Bond, Devereux and Gammie (1996), and the USA (unlimited savings allowance) Tax described in Weidenbaum (1986). The following discussion does not consider a pure wage or payroll tax, a consumption tax option that has not received serious consideration, primarily because its base does not include economic rents or any of the returns to risk-taking. (Toder and Rueben (this volume) note that the Flat Tax is similar to a pure wage tax in its treatment of 


\section{Should Capital Income Be Subject to Consumption-Based Taxation?}

approaches lies in their treatments of capital income, and this paper provides an overview of what is thus the critical question in the fundamental tax reform debate - should capital income be subject to consumption-based rather than income-based taxation.

The paper proceeds as follows. The following section provides an overview of the main issues and defines the subset of those issues that will be addressed in this paper. Section III contains the analysis, which focuses on three central results in the literature as well as a variety of other issues, and Section IV concludes. Finally, before proceeding, I should perhaps note that I am not an entirely unbiased observer in the debate, having been involved in the preparation of several consumption tax prototypes (McLure, Mutti, Thuronyi and Zodrow, 1980; McLure and Zodrow, 1996) and evaluations of the relative merits of income and consumption-based taxation (Zodrow and McLure, 1991; Zodrow and Mieszkowski, 2002).

\section{A Framework for Analysis}

Not surprisingly, it is difficult to separate the topic of this paper - "should we" tax capital income - from the topics addressed in the other papers in this volume, "do we" and "can we" tax capital income. After all, one of the key arguments made by proponents of consumption-based taxation is that it is exceedingly difficult to accurately measure and tax capital income, especially in the face of increasing international capital mobility and tax sheltering activity, and that in practice much capital income escapes taxation under the income tax in the US and indeed in all countries that utilize the tax. Nevertheless, I shall largely abstract from these issues, and focus on the question of whether we should tax capital income, on the assumption that it is possible to do so at a reasonable cost. But before doing so, it will be useful to consider several preliminary issues.

foreign source income, although such income may be taxed abroad and in practice is lightly taxed under the current income tax.) Many of these proposals have been refined over time, especially to take into account administrative issues which play a critical role in choosing among the various consumption tax reform options; for example, see Bradford (2005) and Weisbach (2000, 2003). 


\section{Is a "Pure" Consumption Tax More Likely Than a "Pure" Income Tax?}

First, it is important to note that long experience has proved that it would be difficult to achieve the long advocated ideal of a comprehensive accrual income tax. Practical requirements for a tax based on realizations - loosely speaking, actual sales - rather than on accrued values, coupled with the difficulties in measuring the economic depreciation of productive assets (and a host of similar timing issues) and in adjusting capital income for inflation imply that accurate measurement of an accrual concept of real economic income is inherently exceedingly difficult. ${ }^{2}$ By comparison, the cash flow accounting that characterizes the consumption-based tax reform options is not beset by similar basic conceptual issues. ${ }^{3}$ That is not to say that "real world" versions of the various consumption tax proposals being discussed would not be more complex than their idealized versions, especially in a world in which our trading partners continue to rely on income taxes, or that many of the problems that plague the income tax do not also arise under a consumption tax. ${ }^{4}$ Nevertheless, an important advantage shared by all the consumption-based reform proposals is that consumption is inherently easier to measure than income.

Beyond measurement issues, both the corporate and individual income taxes are riddled with generally highly inefficient but politically very popular special deductions, exemptions and other forms of preferential tax treatment, most of which would be eliminated under the ideal versions of the most prominent consumption tax reform proposals (and could also be eliminated under an

2 For example, see Roin (this volume) and Kleinbard (this volume) for discussions of the difficulties of taxing capital income; also, see Shakow (1986) and Auerbach and Bradford (2004) for discussions of how a comprehensive income tax might be implemented.

3 See Bradford (1986) for a classic exposition of this argument. More recently, McCaffery (2005, p. 809) argues that a "great deal and possibly all of the mind-numbing complexity of America's largest and least popular tax follows from the decision to have a progressive personal income tax," and Shaviro (2004, p. 92) stresses that "a consumption tax could offer enormous simplification advantages."

4 These issues are addressed in the context of a version of the X-Tax by Bankman and Schler (this volume). In addition, see Weisbach (2000), McLure and Zodrow (1996) and Feld (1995) for discussions of problems that would arise in implementing the Flat Tax as well as Bradford (1996a) for problems raised by the taxation of financial institutions under prepaid consumption tax plans, Ginsburg (1995) for a similar analysis of issues raised by the USA tax proposal (which combined a business level value added tax with an individual level cash flow tax), and Murray (1997) for a discussion of problems in implementing a national retail sales tax. Slemrod (2005) discusses the desirability of, and problems raised by, removing popular tax preferences. Note that, as demonstrated by the Bush administration's initial proposals for integrating the corporate and individual income tax systems, ensuring that capital income is taxed once but only once under an income tax integration reform also poses significant administrative problems (Hubbard, 2005). 


\section{Should Capital Income Be Subject to Consumption-Based Taxation?}

income tax reform). A natural question is whether any consumption tax reform that survived the political process could maintain such "purity". Although a heavy dose of skepticism would certainly be appropriate, several factors suggest there may be at least some room for cautious optimism. First, with respect to the corporate tax, the structure of all of the consumption tax reform proposals implies that all new investments, regardless of industry and source of finance, would face a marginal effective tax rate of zero - that is, expensing of new investment is sufficiently generous that an investment that earns normal returns is untaxed. It is possible that a uniform marginal rate of zero on all forms of investment would serve as a natural floor to preferential tax treatment, at least to the extent that there would be greater political resistance to outright subsidies then to mere reductions in tax liabilities, especially given current budget exigencies. $^{5}$ Of course, the fact that recent reforms - including (temporary) accelerated depreciation, extensions of limited expensing for small businesses, reductions in tax rates on capital gains and dividends - as well as proposals for new prepaid savings accounts were not accompanied by proposals to reduce the deductibility of interest expenses (which would be required to avoid subsidies to investments rather than just marginal effective tax rates of zero and indeed to insure that the efficiency gains associated with consumption taxation would be achieved) are certainly not encouraging in this regard. On the other hand, some support for the admittedly tenuous notion of a "zero rate floor" is provided by the experience of the 1980s, as the passage of the Tax Reform Act of 1986 and the elimination of the safe-harbor leasing provisions of the Economic Recovery Tax Act of 1981 were prompted in large part by public outcries at the tax sheltering and tax loss trading associated with negative effective tax rates at the business level.

On the individual side, pressure to maintain popular deductions even within the context of fundamental tax reform would no doubt be intense under any fundamental tax reform. Although one might hope that some of this pressure would be offset by the lure of lower tax rates and the prospect of significant simplification, past experience, even with the largely successful Tax

5 Note that if favorable treatment of some narrow classes of investment were deemed desirable, e.g., in research and development in order to capture significant positive externalities, carefully targeted expenditure programs could 


\section{Should Capital Income Be Subject to Consumption-Based Taxation?}

Reform Act of 1986, suggests that such optimism may be misplaced. However, especially given concerns about the distributional implications of implementing consumption taxes, some limitations on current deductions that would disproportionately affect primarily high income individuals might be palatable as part of a comprehensive tax reform package. For example, the "upside-down subsidy" nature of current deductions for items such as home mortgage interest which arises because the value of the deduction increases with the taxpayer's marginal tax rate as does the extent to which the preference item exceeds the standard deduction - implies that their benefits are highly concentrated among the wealthy (Carasso, Steuerle and Bell, 2005). This suggests that proposals to convert the deduction to a credit and/or subject it to a cap - as well as eliminating the mortgage interest deduction for second homes - might be feasible within the context of a fundamental tax reform package as a means of attaining approximate distributional neutrality and keeping top rates relatively low. More generally, the potential for reemergence of tax preferences after the initial enactment of a relatively "pure" consumption tax reform - at both the business and individual levels - might be limited by the introduction of supermajority requirements for adding preferences or raising tax rates or the reintroduction of "pay-as-you-go" budget rules (Bradford, 2005; Auerbach and Hassett, 2005). Although such measures could of course just as easily be enacted under income tax reform (and indeed might have limited the unraveling of the Tax Reform Act of $1986^{6}$ ), they may be politically more palatable as part of a large-scale reform of the tax structure than under a more modest income tax reform. Finally, as will be discussed further below, elimination of existing deductions could be accompanied by the introduction of new (perhaps capped) deductions for investments in human capital which, in addition to political popularity, have the advantage of being consistent with the principles of consumption-based taxation (Judd, 2001). To sum up, there are several reasons why there is at least some possibility that a new consumption tax, enacted in the context of fundamental tax reform, might be able to attain a greater degree of "purity" than would be possible under an incremental reform of the current income tax; of course, whether such arguments would in the

be utilized rather than general tax preferences.

6 See Steuerle (2004) for a discussion of the Tax Reform Act of 1986 and subsequent revisions of the tax structure. 
end prove compelling and whether such reforms would be sustainable is obviously highly speculative. $^{7}$

Finally, a natural question is whether a consumption tax would be less susceptible to the tax sheltering activity that has plagued the income tax, especially in recent years. ${ }^{8}$ Since Bankman and Schler (this volume) discuss - debate? - this issue at length, I shall make only a few general comments here. As suggested previously, many of the problems of income measurement that arise under the income tax, especially those associated with a realization-based rather than an accrual-based system and with inappropriate accounting for interest income and expense, disappear under a consumption tax, so there is some presumption that tax sheltering would be less of a problem under a consumption tax. For example, Bankman (2004) notes that many of the tax sheltering schemes that have been utilized under the income tax, most of which involve manipulations of provisions related to the taxation of capital income, would not be possible under a consumption tax. On the other hand, the extent to which this would be true in the "real world" would depend a great deal on the specific details of the plan enacted. ${ }^{9}$ For example, Weisbach (2000) argues that the Flat Tax is more easily evaded than some of the other consumption tax options, primarily because it is an "open" tax system that allows business deductions even in cases in which there is no offsetting inclusion (e.g., purchases from individuals, tax-exempt institutions or foreigners). ${ }^{10}$ Similarly, Bankman and Schler (this volume) identify a number of sheltering opportunities under the Flat Tax and the X-Tax, some of

7

International experience with the VAT may also be instructive in this regard. Although VATs are never completely uniform, preferences take the form of applying zero rates to certain commodities (typically on distributional grounds) or exempting certain activities (typically on distributional or administrative grounds), rather than business subsidies that would give rise to negative marginal effective tax rates.

8

This is clearly related to the more general issue of whether a consumption tax would be simpler than an income tax; see Slemrod (1996) and Gale and Holtzblatt (2002) for general discussions of the simplicity properties of the various reform options.

9 Indeed, McLure and Zodrow (1996) argue for a modified version of the X-Tax that would tax both real and financial transactions at the business level partly on the grounds that it would be less susceptible to evasion and avoidance, especially on international transactions.

10 By comparison, under the credit-method value-added tax utilized in Europe and elsewhere, firms get credits on their purchases only to the extent that they have invoices showing that tax has been paid by their suppliers (McLure, 
which involve significant opportunities for tax deferral (most of which would give rise to short run revenue problems without affecting the present value of revenues) and others that would permanently reduce or eliminate tax liability. The message of this paper is that the relative importance of tax sheltering opportunities under income and the various consumption taxes is unclear, partly because there is so little international experience with consumption taxes of the type being discussed currently, ${ }^{11}$ and that this is clearly a topic that merits further study. One obvious implication is that the results of the various economic models that assume effective enforcement and then attempt to estimate the efficiency effects from consumption tax reforms (discussed below) must be qualified for differences in enforceability, including susceptibility to tax sheltering activity - but both the direction and the magnitude of the qualification is unclear.

\section{Consumption-Based and Income-Based Taxation of Capital Income}

As noted above, the essential difference between consumption and income-based taxes is in their treatment of capital income. Although this is sometimes expressed as the notion that the income earned by capital is taxed under the income tax but exempt under a consumption tax, this characterization must be qualified in two critical ways. First, as will be discussed further below, consumption taxes generally apply to capital existing at the time of enactment, although this depends on the nature of the transition rules used during the movement to the new regime. Second, and more importantly for purposes of the current discussion, the differences in the tax treatment of capital income under the two approaches are more subtle than suggested by the simple characterization above (beyond qualifications related to the difficulties of implementing a true accrual income tax). These differences arise because the purchases of investment goods are not included in a consumption tax, either due to exemptions, credits or deductions under the NRST and VAT approaches or due to expensing under the business cash flow tax components of

1987). This is a major advantage of the credit-method VAT over what McLure calls the "naïve subtraction method VAT," which allows a deduction for all purchases.

11 A related question is why this international experience with consumption taxes of the types currently being discussed is so limited (beyond the extensive international experience with indirect consumption taxation in the form of the value-added tax and, to a much lesser extent, retail sales taxes), with the primary examples being the ACE (allowance for corporate equity) taxes implemented in Croatia, Brazil, Italy and Austria (Keen, this volume). Although there are a wide variety of possible explanations, it is clear that a factor that played the critical role in halting several consumption tax reforms was the reasonable concern that the US Internal Revenue Service would not 


\section{Should Capital Income Be Subject to Consumption-Based Taxation?}

the Flat Tax, X-Tax, and other direct taxes. Such treatment is more generous than that provided under an income tax, which allows only deductions for economic depreciation. More specifically, allowing expensing rather than economic depreciation is sufficiently generous in present value to exempt only the normal return to investment. ${ }^{12}$ However, as has been stressed in the recent literature, capital income consists of four conceptually separate components. ${ }^{13}$ The first is the normal or risk-free return that compensates individuals for deferring consumption, often described as the "return to waiting" which, as described above, is in fact tax exempt under a consumption tax but is fully taxed under a comprehensive accrual income tax. Thus, the standard characterization applies for the normal returns to investment. In contrast, the tax treatments of the other three components of capital income are similar under income and consumption taxes. Specifically, since the benefit of expensing is large enough only to exempt normal returns, above-normal returns or economic rents are captured under both taxes. In addition, the returns to risk-taking - both the expected risk premium and any additional (positive or negative) returns that reflect good or bad luck - are treated similarly under both income and consumption taxes; that is, under both tax systems the government effectively becomes a silent partner in the investment, sharing in both its risk and reward, and earns positive expected tax revenues (which can also be viewed as compensation for the additional risk it assumes as a silent partner in private sector investments rather than as tax revenue). Thus, the difference between the tax treatment of capital income under income and consumption taxes is limited to taxation of the risk-free return, which is fully taxed under the former and exempt under the latter.

The implications of this point are quite interesting and have not been fully investigated in the literature. Risk-free real returns to capital have historically been quite low, especially in periods of high inflation, with average rates, depending on the time period, ranging from roughly 0.5-3 percent (Avi-Yonah, 2004). This suggests that the differences between income and consumption

deem a consumption-based business cash flow tax (e.g., under a Flat Tax, and X-Tax or an Aaron-Galper expenditure tax) to be creditable against the domestic tax liability of US multinationals (McLure and Zodrow, 1998).

12 A simple numerical example, taken from Zodrow and McLure (1991), may help clarify this point. **ADD

13 See Weisbach (2004) and Hubbard (2005a) for comprehensive recent discussions, including demonstrations of all the basic points asserted in the text; see also Bradford (1986), Bankman and Griffith (1992), and Hubbard (2002). 


\section{Should Capital Income Be Subject to Consumption-Based Taxation?}

taxes may have been overstated in the literature. ${ }^{14}$ In particular, most computer simulation models used to analyze the economic effects of implementing consumption tax reforms assume perfect competition and certain returns and thus may overstate the extent to which capital income is taxed under the income tax, as well as the efficiency gains obtained by moving to a consumption tax. On the other hand, these models also typically do not model inflation explicitly, and thus understate the extent to which the normal returns component of capital income is taxed under an unindexed income tax. In addition, as stressed by Judd (1997, 2001), to the extent that economic rents are attributable to imperfect competition characterized by significant consumer price distortions (prices in excess of marginal costs), the efficiency costs imposed by capital income taxation are significantly higher because they tend to exacerbate existing price distortions; this in turn implies that the gains from implementing consumption tax reform would be correspondingly greater. Finally, the fact that economic rents and the returns to risk-taking are treated similarly under both taxes mitigates the transition problems associated with moving from an income tax to a consumption tax. ${ }^{15}$ Sorting out the relative magnitudes of all of these various offsetting effects is a useful avenue for future research.

\section{International Issues}

Following most of the existing literature and because international issues are addressed in another conference paper, this analysis will focus on the taxation of capital income in a closed economy. However, international issues play a critical role in the debate regarding the appropriate taxation of capital income. One especially troublesome issue is that a variety of administrative problems would arise if the US were to implement a consumption-based direct tax system while all of its trading partners continued to use income-based direct taxes. In particular, avoidance schemes based on the differential treatment of capital income would be problematic under certain forms of consumption taxation (McLure and Zodrow, 1996), and the transfer pricing problems that plague the income tax would also arise in certain cases (Bradford, 2003;

\footnotetext{
14 This point is stressed by Weisbach and Bankman (2005) and McCaffery (2005). Note, however, that this argument in no way implies that the taxation of normal returns to capital is a trivial issue; see Aaron (this volume).

15 See Lyon and Merrill (2001).
} 


\section{Should Capital Income Be Subject to Consumption-Based Taxation?}

Weisbach, 2000; Avi-Yonah, 2004). On the other hand, adoption of a consumption tax would also allow substantial simplification of international tax rules (Ballard, 2002; Weisbach, 2000).

From a theoretical perspective, open economy factors tend to reinforce the case for consumptionbased tax treatment of capital income. This is especially the case in the context of a small open economy that must take the after-tax return to internationally mobile capital as fixed. In this case, Gordon (1986) and Razin and Sadka (1991) show that the optimal tax rate on capital income is zero. $^{16}$ The intuition behind this strong result is that a fixed international return to capital implies that any tax on capital income will drive out internationally mobile capital from the taxing jurisdiction until its before-tax rate of return rises by enough to entirely offset the tax, so that mobile capital invested in the taxing country earns the same after-tax return that can be obtained elsewhere in the global economy. ${ }^{17}$ This tax-induced emigration of capital lowers the productivity of the fixed factors in the taxing country - land and labor (or at least relatively immobile labor) - and thus lowers wages and land rents. Indeed, as long as the taxing country is sufficiently small, Kotlikoff and Summers $\left(19^{* *}\right)$ show that local factors of production will ultimately bear the entire burden of the capital income tax, including not only the amount of tax revenue but also the efficiency costs associated with the tax-induced capital outflow. ${ }^{18}$ The clear implication is that, solely from the viewpoint of the residents of the taxing country, it is preferable simply to tax local factors directly, and thus avoid at least the excess burden of the tax on capital income.

This result must be qualified in a number of ways. First, capital income taxation may be desirable to capture economic rents that can be earned by investments in the taxing jurisdiction due to unique location-specific characteristics (such as lower transport costs, access to

16 This applies only for production-based taxes on capital income. By comparison, taxes on the capital income of all of a nation's residents, regardless of where it is earned, are theoretically more desirable but in practice exceedingly difficult to implement (Blumenthal and Slemrod, 1995).

17 This result is closely related to the international tax competition literature; see Zodrow (2003) for a recent discussion. 


\section{Should Capital Income Be Subject to Consumption-Based Taxation?}

productive but relatively inexpensive factors of production, and easy access to consumer markets), especially if those rents accrue to foreign owners of capital. Second, source countries frequently attempt to "transfer" tax revenues from countries that tax their multinational corporations on a residence basis but allow foreign tax credits for taxes paid abroad - although this prospect is limited by numerous factors. ${ }^{19}$ Third, the source country may not be appropriately characterized as a small open economy. For example, Gravelle and Smetters (2001) show that for larger economies such as the United States which have significant market power in international capital markets, ${ }^{20}$ the extent to which capital income taxes are borne by domestic labor (as is implied by the small open economy analysis) is significantly reduced when domestic and foreign goods are imperfect substitutes - although their model does not allow for any tax-induced negative effects on saving. This result contrasts with Harberger (1995), who argues that domestic labor may bear significantly more than the full burden of the corporate tax as the general equilibrium effects of tax-induced wage reductions in the corporate sector spread throughout the domestic economy, although this analysis focuses on the case in which the elasticity of supply of international capital to the domestic economy is infinite and is thus more relevant to the small open economy case. Finally, Gordon (1992) notes that, with implicit coordination of capital income taxes through the foreign credit mechanism of countries that use residence-based corporate income taxes, capital income taxation may be desirable because it provides governments with revenues as well as a backup to domestic personal income taxes. Nevertheless, on balance, international capital mobility considerations would appear to create another theoretical argument for reduced taxation of capital income. This argument is generally

18 These efficiency costs arise due to an inefficiently low overall capital intensity of production and a tax bias favoring production of labor-intensive goods (Gordon and Hines, 2002).

19 Specifically, the "treasury transfer" effect is mitigated because (1) many home countries utilize a territorial rather than residence-based system for taxing their multinationals, (2) many countries that tax worldwide income on the basis of residence allow tax sparing which eliminates the "treasury transfer" effect (since the home country allows foreign tax credits for taxes that would have been paid in the absence of source country investment incentives), (3) many multinationals from countries that tax on a residence-based system, especially the US, currently have far more foreign tax credits than they can use, and (4) the value of foreign tax credits is reduced because they are paid only when funds are repatriated to the domestic parent while the source based taxes must be paid currently. See Zodrow (2005) for a recent discussion.

20 Although capital is less than perfectly mobile internationally (Feldstein and Horioka, 1980; French and Poterba, 1993), much recent research suggests that the extent of international capital mobility is significant and increasing over time (Feldstein and Bachetta, 1991; Obstfeld and Rogoff, 1995; Coakley, Kulasi and Smith, 1998). 


\section{Should Capital Income Be Subject to Consumption-Based Taxation?}

supported by simulation models of the effects of consumption tax reforms, as growth of the domestic capital stock, labor productivity and wages is augmented by inflows of international capital (although the taxation of such foreign direct investment is limited to the taxation of economic rents) and returns to capital decline less than in the closed economy case. ${ }^{21}$ For example, in a recent review, Ballard (2002, pp. 137-8) concludes that "fundamental tax reform in the United States would lead to aggregate welfare gains, and ... these gains would be larger in an open-economy context." Given recent low savings rates in the US and the concomitant reliance on foreign capital, such concerns are especially important.

\section{AN OVERVIEW OF THE Literature ON THE DEBATE}

The debate regarding the relative desirability of income and consumption taxation dates back to Hobbes, Marshall and Mill; it was rekindled some thirty years ago by the seminal work of Andrews (1974) as well as the highly influential reports of the US Treasury (1977) and the Meade Committee in the UK (Institute of Fiscal Studies, 1978), and continues unabated to this day. The debate has generated a voluminous literature, ${ }^{22}$ which implies that the following discussion is necessarily selective. The approach I take is to focus initially on what I believe to be the three most important sets of results in the literature on optimal capital income taxation, as well as various qualifications to those results, and then consider some additional issues.

\section{Results from Infinite Horizon Models Analyzing Efficiency Issues}

The most striking result in this literature is due to the seminal contributions of Judd (1985) and Chamley (1986), who analyze optimal capital and wage income taxation in models in which individuals are assumed to be infinitely lived. Although such models are used to some extent

\footnotetext{
21 Note, however, that there are offsetting effects, as some of the tax-induced increases in personal saving go abroad (Goulder, Shoven and Whalley, 1983) and some of the welfare gains accrue to foreign residents. In addition, Grubert and Mutti (1985) show that even limited international capital mobility is sufficient to have a significant impact on an analysis of the effects of reform.

22 For recent surveys, see Zodrow and McLure (1991), Gravelle (1994), Gordon (2000), Judd (2001), McCaffery (2005) and Weisbach and Bankman (2005).
} 
because they are analytically tractable, they can be loosely justified as a representation of the situation in a parent's welfare depends on her children's welfare, and thus on her grandchildren's welfare, etc. Within this context, Judd and Chamley show that in the long run the optimal capital income tax rate is zero. The intuition behind this result is straightforward. By reducing the aftertax interest rate, a capital income tax increases the price of future consumption relative to current consumption. Although this distortion may be modest over a short time interval, it increases exponentially with time, so that even a small capital income tax rate will eventually be highly distortionary. Since the individuals in these models have perfect foresight over an infinite lifetime, their consumption patterns are highly distorted by such a tax, with significant declines in saving and capital accumulation. Indeed, in the Judd (1985) model, which has both representative workers and capitalists, the negative effects of a capital income tax on saving and capital accumulation and thus labor productivity and wages are sufficiently great that the optimal capital income tax rate is zero even if the government is concerned only about the welfare of workers. ${ }^{23}$ A second message of the infinite horizon models is that even though capital income taxation should be avoided entirely in the long run, existing capital should be taxed to the maximum extent feasible since such taxation represents a nondistortionary or "lump sum" source of revenue. ${ }^{24}$ Similarly, confiscatory capital income taxation may be desirable in the short run while capital-tax-induced distortions are relatively small. ${ }^{25}$

This result does not depend on the nature of individual preferences, and has been extended to models with exogenous growth (Lucas, 1990), stochastic shocks to production (Chari, Christiano and Kehoe, 1994), heterogeneous capital goods and imperfect competition (in which case Judd (1997) shows that the optimal capital income tax rate is negative), and various patterns of government expenditures (Judd, 1999).

Although the practical relevance of this result is generally quite limited, it is interesting to note that implementation of a consumption tax may, depending on transition rules, achieve this result; this point is discussed further below. Note also that such a policy suffers from a "time inconsistency problem" in that although it may in principle be desirable to impose a huge tax on existing capital as part of an agreement to exempt future returns to capital, investors will understandably be suspicious that future governments will renege on the agreement and tax future accumulations of capital, in which case the predicted positive effects on saving and capital accumulation will not fully materialize.

25

A related result is obtained by Saez (2002a), who constructs a model in which the use of progressive capital income taxes (flat rate taxes above an exemption level) may be used for a finite time period to reduce wealth accumulations existing at the time of the enactment of reform. 
Since the infinite horizon models are characterized by relatively large saving responses, they tend to imply relatively large growth effects from implementing consumption tax reforms (Engen, Gravelle and Smetters, 1997). Indeed, based on an infinite horizon modeling approach, Lucas (1990, p. 314) argues that proposals to exempt capital income from taxation would deliver "the largest genuinely free lunch I have seen in 25 years in this business, and I believe we would have a better society if we followed this advice." Nevertheless, the policy implications of these results are open to debate. In particular, Jones, Manuelli and Rossi (1993) and Milesi-Ferretti and Roubini (1998) argue that the logic underlying the desirability of tax exemption of the income from physical capital in the long run in such models also applies to the accumulation of human capital; that is, returns to human capital investments should also be exempt from tax. To the extent that the costs of obtaining human capital are foregone earnings and the tax system is proportional, this is not an issue, as the implicit deductibility of foregone earnings, coupled with taxation of the returns to the investment in the form of future wages, implies that returns to investment in human capital are in fact untaxed (as such treatment corresponds to that of saving under a cash flow consumption tax). However, to the extent that the direct costs of making an investment in human capital (e.g., tuition, books and fees) are not deductible, the resulting wage income should not be taxed. Thus, tax exemption of the income to physical capital under a consumption tax should be accompanied by the deductibility of the direct costs of investing in human capital, to the extent such investments do not reflect consumption expenditures (Judd, $2001)^{26}$

26 Early research suggested that the neutral treatment of investment in human capital (financed with foregone earnings) and investment in physical capital was an important advantage under a consumption tax, relative to an income tax which creates an inefficient tax bias toward investment in human capital by taxing only the returns to investment physical capital (Driffill and Rosen, 1983). However, in addition to its political appeal, a bias favoring human capital accumulation may be desirable to offset (1) the effects of a progressive tax system, under which the implicit deductions for foregone earnings are taken at a low rate while the subsequent returns to investment (future wages) are taxed at a relatively high rate (Dupor, Lochner, Taber and Wittekind, 1996), (2) the absence of deductions for most direct costs of investment human capital, including tuition, books and fees (Nerlove, 1992), and (3) the differentially high risk associated with undiversifiable investments in human capital (Eaton and Rosen, 1980; Judd, 1998). Moreover, recent work by Taber (2002) suggests that the efficiency costs of income taxation of human capital investment are short-lived, and the transition to a new efficient equilibrium is fairly rapid. Thus, the efficiency benefits of improved tax treatment of human capital investment under the consumption tax may be fairly limited - and in any case, expenditure policy, which already plays a major role in reducing the effective cost of education in the US, is a better targeted and thus less costly means of correcting for any perceived problems in human capital formation (e.g., underinvestment due to liquidity constraints). 
More importantly, many observers hesitate to draw policy implications from models that assume infinitely-lived individuals. Beyond questions regarding the validity of using infinitely-lived individuals as a representation of altruism across generations, such models cannot address the critical issues related to intergenerational redistribution and transitional problems that are raised by consumption tax reforms. Accordingly, most of the policy analysis of consumption tax reforms has focused on lifecycle models with an overlapping generations structure. ${ }^{27}$

\section{Results from Life-Cycle Models Analyzing Efficiency Issues}

The simplest version of the traditional lifecycle model is characterized by the same basic structure as that described above, except that the representative individual has a two-period life cycle, supplying labor (demanding leisure), purchasing consumption goods and saving during the first "earnings" period, and consuming by drawing down savings during the second "retirement" period. As above, a tax on wage income in this context is equivalent to a uniform tax on consumption in the two periods, while a tax on capital income reduces the after-tax return to capital and thus effectively acts as a tax on future consumption. This problem is thus analogous to the often-studied issue of whether uniform or differential taxation of consumption commodities is optimal. As is well known, uniform commodity taxation is efficient only under certain circumstances, and analogous results obtain in this case. Specifically, the optimal capital income tax rate is zero (implying uniform taxation of consumption in both periods, as would occur under a consumption or wage tax) only if first and second period consumption are equally complementary with leisure. ${ }^{28} 29$ The intuition underlying this result reflects a balancing of two considerations. On the one hand, uniform taxation of consumption in the two periods tends to be efficient, as it avoids tax distortions of intertemporal consumption allocation decisions. On the

27 Note, however, that the insight that capital income taxes are highly distortionary for individuals with long time horizons are still relevant, if to a lesser degree, in lifecycle models. Indeed, because lifecycle models often assume away intergenerational altruism entirely, they may be understating the gains from consumption tax reform.

28 For example, see Feldstein (1978), Bradford (1980), King (1980) and, in an explicitly dynamic context, Atkinson and Sandmo (1980).

29 Goods that are complements tend to be consumed together. More formally, leisure and a consumption good are complements if an increase in the price of the consumption good reduces the demand for leisure (and thus increases labor supply). 
other hand, the inability to tax leisure directly implies that taxation of the consumption goods will inefficiently reduce labor supply, so that differential taxation of consumption goods will be desirable if it can be used to offset the tax-induced increase in leisure demand and the associated reduction in labor supply. However, if consumption in the two periods is equally complementary to leisure and thus affects labor supply in the same way, any rationale for differential taxation disappears, and uniform commodity taxation (a capital income tax rate of zero) is optimal.

As shown by Auerbach (1979), this condition obtains if individual tastes meet two requirements, hereafter referred to as the uniform commodity taxation (UCT) conditions. First, individual tastes must be "separable" in leisure and the two consumption goods - that is, decisions regarding choices among consumption commodities must be independent of the decision regarding how much labor to supply (leisure to demand). Second, individual tastes must be "homothetic" with respect to the consumption goods, which implies that increases in wealth are distributed proportionately across consumption in all periods. There is of course no guarantee that individual tastes will satisfy these two UCT conditions. However, homotheticity is consistent with the generally accepted permanent income hypothesis, and indeed is a standard feature of most lifecycle model formulations. Separability of consumption and leisure is more tenuous but, as argued by Atkinson and Stiglitz (1980, p. 437), it provides a reasonable benchmark that is based on "an assumption that has been made in nearly all studies of demand and labor supply functions." 30 It is also important to note that income taxation corresponds to a tax rate on capital income that is not merely positive but equal to the tax rate on wage income. If the "optimal" tax rate on capital income is positive but relatively small, the administrative costs associated with taxing capital income at a positive rate suggest that a consumption-based tax may be preferable to an income tax. ${ }^{31}$ In sum, the simple two-period model arguably suggests a

30

Moreover, Balcer, Garfinkel, Krynski and Sadka (1983) argue that even in situations in which the UCT conditions are not satisfied and differential commodity taxation is theoretically desirable, the efficiency gains relative to a uniform commodity tax are quite small; moreover, these results were obtained within the context of taxes on various commodities within a single period, and it seems likely that differences in complementarities with leisure would be significantly greater across different types of consumption goods than across aggregate consumption in different periods, suggesting that uniform taxation is closer to optimal in the latter case.

31 Alternatively, such a result supports use of the "dual" income tax, adopted in the late 1980s and the early 1990s by the Nordic countries (Denmark, Finland, Norway and Sweden), under which capital income is taxed at a single 
presumption that an optimal tax system is, or is approximated by, tax exemption of capital income.

Note also that the applicability of the simple two-period model is limited. Two obvious concerns are that for a more complete analysis individual lifecycle optimization must be combined with production and incorporated into an overlapping generations structure of the economy, and that the two-period model is an oversimplified representation of earnings, consumption and savings decisions. These two concerns are addressed in a seminal paper by Summers (1981), who constructs an overlapping generations model of an economy comprised of lifecycle savers, each of whom maximizes utility over a fifty-year adult life, the last ten of which are spent in retirement. By assuming fixed labor supply, Summers abstracts from the leisure complementarity issues described above and instead focuses on the allocation of consumption over the lifecycle. He emphasizes that an increase in the tax rate on capital income reduces the after-tax discount rate individuals use in estimating their human wealth - the present value of all future labor earnings - when making consumption and savings decisions. The resulting increase in human wealth prompts greater consumption early in life, that is, less saving. The simulations reported by Summers suggested that this human wealth effect is highly significant and results in large reductions in savings, which in turn implies that the enactment of a consumption tax reform results in large steady state welfare gains. For example, in one central case, the enactment of a cash flow consumption tax results in a steady state welfare gain equal to $11.2 \%$ of lifetime income. ${ }^{32}$ The enactment of a wage tax in the Summers model also increases steady state

relatively low proportional rate at either the business or individual levels, while labor income is taxed at progressive rates under the personal income tax (Sorensen, 1994; Nielsen and Sorensen, 1997). The Nordic dual income tax represents an innovative compromise between the arguments supporting full and zero taxation of capital income; this is especially true for small open economies that are concerned about the tax-induced capital outflows and transfer pricing problems associated with high capital income tax rates, but nevertheless wish to tax economic rents, including those of foreign capital owners, and take some advantage of any treasury transfer effects available from multinationals based in countries that grant foreign tax credits. However, the structure of the dual income tax structure creates a strong incentive to disguise labor income as capital income, especially for small-business owners, and measures designed to combat this evasion problem may be ineffective or instead may result in over-taxation of capital income. Moreover, economic rents and the returns to risk-taking are taxed at relatively low rates, foregoing relative efficient sources of revenue. Finally, in practice, the Nordic countries provide for preferential treatment of certain forms of capital income, even relative to the dual income tax rate structure (Cnossen, 2000). For further discussion, see Zodrow (2005).

32 One reason for the large welfare gains obtained with a consumption tax reform is that the size of the existing capital stock under the income tax is suboptimal in the Summers model, which is reflected as an equilibrium return 
welfare, but to a significantly smaller extent ( $7.0 \%$ of lifetime income), since existing capital is not subject to tax..$^{334}$

The Summers model sparked a great deal of interest and additional research. Much of this research focused on the extent to which the savings responses in the Summers model (savings elasticities with respect to the after-tax rate of return on the order of 1-3) are sensitive to various choices about model structure and parameter values (Evans, 1983; Starrett, 1988) and appear to be unreasonably large in light of the fairly small responses estimated in the empirical literature (Ballard, 1990, 2002; Gravelle, 2002). In addition, the assumptions made by Summers of an inelastic labor supply and wages that increase exponentially over the earnings period and thus tend to inflate the human wealth effect are problematical. ${ }^{35}$ These issues are addressed in the overlapping generations general equilibrium model constructed by Auerbach and Kotlikoff

to capital that significantly exceeds the steady state growth rate; such an assumption seems plausible and is consistent with the often-expressed concern that the US saves and invests too little. Note, however, that many other non-tax government policies also affect the level of saving and the size of the capital stock, including investments in public capital, the size of federal deficits (including those associated with the Social Security and Medicare programs), federal support of research and subsidies to human capital accumulation, etc. Thus, the net effect of the government on the level of saving and on the capital stock, and the extent to which the size of the capital stock is too small or too large, is difficult to ascertain.

33

This highlights the point, noted above, that a significant fraction of the efficiency gains obtained from a consumption tax reform is attributable to a one-time "hit" on old capital, reminiscent of the tax on existing capital that characterizes the infinite horizon models

34

Note, however, that the wage tax in the Summers model is not accompanied by a cash flow business tax, and thus does not reflect the effects of enacting a Flat Tax which, in the absence of transition rules, would also include a lump sum tax on existing capital due to the loss of depreciation deductions under the business tax. A separate issue is the treatment of the government budget constraint. Summers assumes that the government's budget must be balanced each year. As a result, any policy that defers taxes, such as a cash flow consumption tax or an income tax, will stimulate additional savings as individuals must save to finance the payment of future taxes; this additional saving would not occur under a wage tax reform, which reduces its savings effects and thus the long run welfare gains associated with its enactment.

35

A separate issue, discussed further below, is the tax treatment of bequests, a difficult issue as bequest motives are not particularly well understood and the effects of including bequests depends on how they are modeled; see Diamond, Johnson and Zodrow (1997) for a discussion. The effect of adding bequests is fairly small if they are simply modeled as another element in the utility function (Seidman, 1983). If individuals are instead assumed to have a "target" bequest motive, the efficiency gains from consumption-based taxation of capital income are reduced because an increase in the after-tax rate of return facilitates attainment of the bequest target and thus reduces saving. Alternatively, if bequests are modeled by assuming altruism on the part of parents toward the welfare levels of their children, the analysis becomes similar to that of infinitely-lived individuals, in which capital income taxes are highly distortionary and consumption taxation is optimal. In a life cycle context, the analysis is complicated further by the fact that bequests generate benefits to both the donor and the recipient, which implies that subsidies could be justified. For excellent recent discussions of the many issues raised by the tax treatment of bequests, see the articles in Gale and Slemrod (2001). 


\section{Should Capital Income Be Subject to Consumption-Based Taxation?}

(1987). ${ }^{36}$ The AK model allows labor-leisure choices in each period, assumes a "hump-backed" wage profile over the lifecycle taken from the labor economics literature, and uses more conservative parameter values than those utilized by Summers.

As a result of these and many other differences from the Summers model, the welfare gains obtained from the enactment of a consumption tax reform in the AK model are more moderate. For example, in a base case analysis, enactment of a cash flow consumption tax increases steady state welfare by $2.3 \%$ of the present value of "lifetime resources," a broader measure of welfare than that used by Summers as it includes the value of leisure. ${ }^{37}$ More recently, Auerbach (1996) uses an updated version of the AK model to analyze the effects of several of the consumption tax proposals discussed above. ${ }^{38}$ He estimates that enactment of a retail sales tax or a value-added tax would increase long run steady state welfare by $1.9 \%$ of lifetime resources; this corresponds to an efficiency gain, measured as the sustainable increase in welfare for all future generations, using lump-sum redistributions to hold constant the utility levels of all individuals alive at the time of enactment, equal to $6.4 \%$ of lifetime resources. By comparison, due to its standard deduction and personal exemptions, enactment of the Hall-Rabushka Flat Tax results in smaller welfare and efficiency gains, as steady state welfare increases by $1.6 \%$ and the efficiency gain is more than halved to $2.8 \%$. Auerbach also considers adding transition rules to the Flat Tax in the form of allowing continued deductions for depreciation on existing assets. As discussed below, such transition rules mitigate the tax-induced decline in the values of existing assets associated with a consumption tax reform; however, reducing the magnitude of this windfall loss imposed on existing capital owners also reduces the long run efficiency gains attainable with reform. Specifically, in Auerbach's simulations, the steady state welfare increase drops to $0.67 \%$ and the long run efficiency gain drops to $2.2 \%$ of lifetime resources. Thus, a central message of Auerbach's analysis is that reform-induced efficiency gains vary significantly across

36 See Auerbach (1996) for a recent analysis of fundamental tax reform using the AK model, and Kotlikoff (1998) for a discussion of its evolution.

37 By comparison, for the same reasons as in the case of the Summers model, the enactment of a wage tax (again without a complementary business tax) reduces welfare by $0.9 \%$ of the present value of lifetime resources. 
consumption tax reforms, and are negatively affected by adding progressivity and transition rules. ${ }^{39}$

Although the analyses by Auerbach and Kotlikoff evaluate the relative merits of income and consumption taxes, they do not directly address the issue of the optimal tax treatment of capital income in an overlapping generations model populated by individuals who optimize over a life cycle consisting of many periods. This issue is addressed in an excellent recent paper by Erosa and Gervais (2002), hereafter, EG. ${ }^{40}$ These authors construct a model that is generally similar to that utilized by AK, except that the government has complete flexibility with respect to debt policy. In calculating "optimal" tax rates in the model, the government is assumed to maximize a weighted sum of individual welfare levels across generations. In this context, EG show that a capital income tax rate of zero is optimal only if the UCT conditions are satisfied and labor income tax rates vary appropriately with age, with low (high) rates when leisure demand is high (low) and relatively inelastic (elastic). ${ }^{41}$ Since age-dependent wage income taxes are infeasible, EG investigate whether their effects can be approximately replicated with the appropriate pattern of capital income tax rates, and find that some capital income taxation is in fact typically optimal since the optimal time path of age-dependent wage tax rates tends to increase over most of the lifecycle. However, their simulation results suggest that this effect is modest, with optimal capital income tax rates ranging from roughly $4-15 \%$, or $30-35 \%$ of the tax rate on wage income. As suggested above, given the significant administrative costs of attempting to tax capital income at any level, the EG results could easily be interpreted as implying that the optimal tax

\footnotetext{
38 See also Kotlikoff (1995).

39 Indeed, Auerbach also estimates that the efficiency gains associated with implementing the USA tax (Weidenbaum, 1996), which provides for transition rules and multiple individual tax rates that range up to $40 \%$ as well as a variety of other features, are only $0.1 \%$ of lifetime resources.

40 See also Garriga (2003).

41 The additional complexity of age-conditioned labor income tax rates is required because, in contrast to the infinite-horizon models where consumption and leisure are constant in the steady state for the representative individual, consumption and leisure vary over the life cycle in an overlapping generations model. Note that the pattern age-dependent wage tax rates is consistent with the standard Ramsey optimal taxation principle of taxing inelastically demanded goods at relatively high rates (Auerbach and Hines, 2002). In addition, the optimal agedependent wage income tax rates depend inversely and fairly sensitively on the social welfare weights assigned to various generations.
} 
rate on capital income is sufficiently low that tax exemption under a consumption tax may be

desirable. $^{42}$ Nevertheless, further investigation of the optimality properties of AK-type models is certainly warranted, as is an examination of the relative efficiency costs in these models of moving from the optimum toward either pure consumption or pure income taxation, since such "pure" policies are likely to be desirable, once the relatively large administrative costs of hybrid systems are recognized. ${ }^{43}$

\section{Results from Models Analyzing Efficiency and Equity Issues}

Although the analysis thus far has focused exclusively on efficiency issues, equity concerns are central to the debate regarding the desirability of taxing capital income. Both horizontal equity (equal treatment of equals) and vertical equity (progressivity) issues have been addressed in the literature.

\section{Horizontal Equity}

With respect to horizontal equity, a central issue is the time period over which ability to pay tax should be measured. If this period is a single year, then potential rather than actual annual consumption is a plausible measure of ability to pay, and a comprehensive measure of income including all accrued capital income, often referred to as Haig-Simons income, is typically viewed as the appropriate tax base. In this case, horizontal equity implies that individuals with the same comprehensive income in a given year should pay the same tax.

However, the rationale underlying the Haig-Simons ideal has been questioned by consumption tax proponents. For example, Bradford (1980), drawing on the basic lifecycle model, argues that

42 Alternatively, the EG results provide support for a Nordic dual income tax under which the tax rate on capital income is significantly lower than the tax rate applied to labor income.

43

In addition, an examination of the effects of relaxing the EG assumption of a perfectly flexible debt policy would be very useful, as the political feasibility of such a policy is questionable. Flexible debt policy in the EG model plays an important role, as debt can be used to offset the negative effects of consumption tax reform on the elderly if the social weight on current generations is relatively high, or to finance lower future taxes with the accumulation of current surpluses if the weight on future generations is relatively high; for example, in one case analyzed by EG, the government runs a surplus equal to three times in GDP in order to finance lower future tax rates. 
individual welfare is a function not of annual income but of consumption over the lifetime, subject to a lifetime budget constraint. In this case, the appropriate measure of ability to pay is an individual's "endowment" - the present value of lifetime wage earnings - and capital income merely represents compensation for deferred consumption. ${ }^{44}$ In this context, both a (proportional and permanent) tax on consumption and a tax on wages satisfy the criterion of horizontal equity, as the lifetime tax burdens under each approach are equal in present value, and equal the product of the tax rate and the present value of the endowment, independent of individual consumption and saving decisions. By comparison, an income tax which taxes the return to saving penalizes savers; that is, individuals who tend to earn their income early in life or consume late in life will face a higher lifetime tax burden than individuals who have identical endowments but tend to be late earners or early consumers. Bradford argues that this implies that a consumption tax is inherently preferable on horizontal equity grounds, and this view, while not universally accepted, appears to have considerable support. ${ }^{45}$

A closely related issue is whether this argument should be extended to multiple generations. ${ }^{46}$ In particular, the "dynastic" view of horizontal equity implies that economic resources should not be taxed until actually consumed, which implies that bequests should be tax exempt as they represent a transfer of potential consumption to heirs. Under a prepaid tax like the Flat Tax or the $\mathrm{X}$-Tax, this implies that inheritances should not be included in the tax base of the recipient (since the tax has been prepaid); under a postpaid expenditure tax, this implies that "withdrawals" that are used to fund bequests should not be taxed, but should be included as cash inflows in the tax base of the recipient so that they can be taxed when consumed. The sales tax or value-added tax approaches are inherently consistent with the dynastic view of equity, as tax is not assessed until consumption actually occurs.

\footnotetext{
44 As will be discussed below, when the basic lifecycle model is extended to include bequests and inheritances, the value of the individual endowment should include inheritances and bequests should be treated as consumption.

45 See Burman (this volume).

46 See Zodrow and McLure (1991) for further discussion of this issue.
} 
By comparison, the "lifetime endowment" view of equity underlying the lifecycle model described above argues that an individual should be taxed on all resources available during his or her lifetime, including inheritances, regardless of whether they are used for consumption or bequests. This view of equity can be viewed as the lifetime analog to Haig-Simons income, as it implies that the correct base for measuring ability to pay tax over the lifetime is lifetime income including inheritances, regardless of how it is used (Aaron and Galper, 1985). Under a prepaid tax like the Flat Tax or the X-Tax, this implies that inheritances should be included in the tax base of the recipient, implying that both the recipient and the donor (since the tax has been prepaid) will pay tax on the funds transferred. Under a postpaid expenditure tax, this implies that "withdrawals" that are used to fund bequests should be taxed, and should also be included in the base of the recipient. Proponents of the dynastic equity view argue that such treatment introduces an element of income taxation into a tax system that is ostensibly based on consumption, and creates a tax bias against both saving and transfers in the form of bequests relative to other forms. In contrast, proponents of the lifetime endowment view of equity argue that such treatment is essential to ensure that all individuals with the same lifetime resources are treated equally (and to limit the transmission of huge fortunes across generations). The choice between the two approaches obviously involves personal value judgments. However, it is important to note that the choice between the dynastic and lifetime endowment views of equity has similar implications for the designs of both income and consumption taxes; it is an issue for the choice between the two taxes primarily to the extent that capital income taxation is perceived to supplement poorly administered (or substitute for non-existent) estate taxes. ${ }^{47}$

\footnotetext{
47 Cremer, Pestieau and Rochet (2003) show that capital income taxation may be desirable in a version of the Atkinson and Stiglitz (1976) model, modified to include bequests that are by assumption tax exempt, if the equity gains from indirectly taxing inherited wealth offset the efficiency costs of reducing saving and investment. Note also that capital income taxation can be justified as a proxy for a wealth tax that is assessed on the grounds that wealth confers utility beyond its consumption value in the form of prestige, security, and power, including political power (Carroll, 2000). However, consistent with the dynastic view of equity, Shaviro (2004) argues that such benefits reflect only the value of future consumption, which would be fully taxed under a consumption tax (although there would be no reduction in wealth accumulation under a consumption tax, in contrast to the case under an effective capital income tax).
} 


\section{Should Capital Income Be Subject to Consumption-Based Taxation?}

\section{Vertical Equity}

The vertical equity or progressivity of the tax system is also a contentious issue in the income versus consumption tax debate. Although a discussion of the optimal progressivity of the tax system is far beyond the scope of this paper, the following discussion examines whether capital income taxation is necessary to achieve vertical equity goals.

This issue is addressed in a seminal paper by Atkinson and Stiglitz (1976) (hereafter, AS) which focuses on optimal commodity taxation but can, like the studies discussed above, also be applied to analyze the optimal taxation of consumption across periods. The AS model focuses on whether differential commodity taxation is desirable to achieve a society's vertical equity goals (captured in a social welfare function that is a weighted sum of individual utility levels) if a nonlinear tax on wage income is also available and individuals differ only in their skill and thus in their wage levels. Within this context, AS show that if the UCT conditions are satisfied and the nonlinear tax on wage income is set optimally, differential commodity taxation is unnecessary. The intuition behind this striking result is that optimal use of the nonlinear wage tax is sufficient to achieve all distributional goals, since individuals differ only in their skill levels, and at any given skill level all individuals have the same earnings and consumption pattern. Thus, the nonlinear wage tax used in isolation can achieve the socially desired distribution of income, as the only reason to also use distortionary commodity taxes would be to lessen the labor-leisure distortions resulting from the wage tax, but the UCT conditions imply that this is impossible. $^{48}$ As above, in the dynamic analog the consumption goods are interpreted as consumption in various periods in the lifecycle, and the result implies that capital income taxation - that is, differentially high tax rates applied to future consumption - is undesirable. ${ }^{49}$

\footnotetext{
48 Kaplow (2004) extends this result to the case in which the tax on wage income is not set optimally.
}

49 Of course, if the UCT conditions are not satisfied, then capital income taxation would be desirable if future consumption is relatively more complementary with leisure demand. However, as argued by Gordon (2000), high levels of labor supply in the form of a large number of hours worked and later retirement seem to be positively correlated with skill levels, which would imply that for high income individuals consumption is relatively more substitutable for leisure, which in turn would suggest that capital income subsidies are desirable for such individuals. 
A number of recent papers provide arguments for capital income taxation in the context of the AS model. For example, Naito (1999), extending the work of Stiglitz (1982), shows that differential commodity taxation may be desirable if labor is not homogeneous because it alters wages of high and low-income workers and thus may help to achieve vertical equity goals. However, Saez (2004) shows that this result obtains only in the short run, and thus does not provide a compelling argument against a permanent move to a progressive consumption tax.

Saez (2002) shows that if demands for leisure and consumption goods vary within a given skill class, then differential commodity taxes may be desirable to supplement the redistribution that occurs under the progressive wage tax. In a dynamic context, the implication is that (1) if more able individuals within an observed income class tend to save more, and (2) as a result of higher savings levels, these individuals attain a higher level of welfare, then taxes on saving (future consumption) are desirable. The practical relevance of this result, however, is open to question. As noted by Bankman and Weisbach (2005), the link between ability and savings behavior has not been conclusively established, although Lawrence (1991) provides some empirical evidence to this effect. More generally, implementing the results of the Saez analysis requires basing tax policy on an inference about the specific nature of unobservable individual utility functions, rather than using the widely accepted approach of basing tax liabilities on a more easily measurable concept such as income or consumption. Note also that Saez does not estimate the quantitative significance of his qualification to the AS result. Finally, in the current environment in which low national savings rates are a perennial concern, the desirability and political feasibility of a policy designed explicitly to penalize savers seems highly questionable.

The implications of the analysis thus far are that consumption-based taxation is preferable to income taxation on horizontal equity grounds, and that at least in theory vertical equity goals can be achieved with a suitably progressive consumption-based tax, such as Bradford's X-Tax or a progressive expenditure tax. ${ }^{50}$ Indeed, a tax system that at least roughly replicates the

50 Note that in addition to the vertical equity rationale, progressive taxation effectively provides social insurance against income fluctuations (Varian, 1980). 
progressivity of the current tax system across income classes seems to be a prerequisite for reform in most (although by no means all) circles; in particular, the charge of the President's Advisory Panel on Federal Tax Reform specified that an "appropriate" degree of progressivity was an essential element of a reformed tax structure. ${ }^{51}$ It is also clear that such a result cannot be obtained with the implementation of a Flat Tax or a national retail sales tax (or VAT) plus rebate plan - many studies have demonstrated that although these plans are successful in avoiding a tax increase on lower income households (as long as the Earned Income Tax Credit is maintained), they involve a shift in tax burden from the very wealthy to a broadly defined middle class (Mieszkowski and Palumbo, 2002; Feenberg, Poterba, and Mitrusi, 1997). ${ }^{52}$ Such a redistribution of tax burdens is widely seen to be undesirable, especially in light of the dramatic increase in income inequality that has occurred over the past thirty years. Indeed, this concern is sufficiently important that Robert Hall, one of the creators of the original Flat Tax plan, now argues that a "tax design to fit the times might have two or even three different tax rates at the personal level" (Hall, 2005, p. 75). ${ }^{53}$

A natural question is whether the current distribution of the tax burden could in practice be replicated under a progressive consumption-based tax. Note that such a replication is facilitated because the recent increase in income inequality is attributable primarily to an explosion in labor

51

Note, however, that even a "distributionally neutral" consumption tax reform will cause redistributions within income classes. Moreover, since low income individuals pay little or no income tax and middle income individuals already largely receive consumption tax treatment since most of their saving is in housing or retirement plans (Toder and Rueben, this volume), these redistributions will be concentrated in the upper income classes, especially at the very top. Burman (this volume) makes the plausible argument that as long as reform is roughly distributionally neutral in the bottom four quintiles, redistributions among the top quintile may be of relatively little social concern.

52 As discussed in Fullerton and Rogers (1993), lifetime incidence analyses are preferable to studies based on annual income because they limit mismeasurement due to income fluctuations attributable to cyclical and lifecycle factors. For a dissenting view, see Barthold (1993).

53 The exact nature of such a progressive consumption tax is of course a critical issue as well. Although discussions of the relative merits of the various approaches is beyond the scope of this paper, see Hall (2005) and Bradford (2005) who make the case for the Bradford X-Tax, and McCaffery (2005) who argues that a progressive personal expenditure tax is the preferred option. McLure and Zodrow (1996) advocate a hybrid progressive consumption tax which they argue combines the best features of the two approaches. Note that, in contrast to proportional taxes, a progressive expenditure tax tends to subsidize capital income since deductions for saving taken during the earnings years are typically taken at rates higher than those applied to withdrawals from savings in years of retirement. In contrast, the (progressive) X-Tax tends to tax capital income indirectly since wages that are saved during the earnings years are taxed at relatively high rates (although the X-Tax reduce this problem by allowing post-paid treatment of pension plans). 
compensation levels at the very highest end of the income distribution and because capital income has become increasingly less concentrated over time (Piketty and Saez, 2003). As long as the consumption tax system captured all elements of executive compensation to the same extent as current law (e.g., treating executive pay in the form of stock options as labor compensation subject to the individual level tax), these factors suggest that maintaining the present level of progressivity under a consumption tax would be feasible. ${ }^{54}$

Nevertheless, it is clear that approximately replicating current tax burdens would be require a progressive consumption tax rate structure with potentially high maximum tax rates. For example, Toder and Rueben (this volume) perform a static revenue estimate of the effects of moving toward a progressive $\mathrm{X}$-Tax with no transition relief, while maintaining current tax preferences not related to capital income, including deductions for charitable contributions and state and local taxes, and conclude that a revenue and roughly distributionally neutral reform would require a corporate tax rate and a top individual rate of 44 percent. Such estimates, however, are subject to the criticism that they miss the primary advantages of a consumption tax reform stressed by its proponents, including its efficiency-enhancing behavioral responses, and overstate the regressivity of consumption taxes by focusing on annual rather than lifetime incidence measures.

These issues are addressed by the analysis of Altig, Auerbach, Kotlikoff, Smetters and Walliser (2001), who extend the AK model to include 12 lifetime income groups (ten deciles, with the top (bottom) decile split into the top (bottom) $2 \%$ and the remaining 8 percent). Their simulations indicate that enactment of an X-Tax with a top marginal rate of 30 percent results in a long run increase in output of $6.4 \%$, coupled with long run welfare increases for each of the twelve lifetime income classes of between 1-2 percent of full lifetime resources (including leisure). These gains, however, are accompanied by transitional losses for the elderly at the time of

54 Note that one potential advantage of the postpaid expenditure tax approach is that it may be relatively less susceptible to evasion in the form of converting labor income to exempt capital income (Weisbach, 2000), although many such strategies are limited under the prepaid Flat Tax and X-Taxes by setting the top individual tax rate equal to the flat business tax rate. 


\section{Should Capital Income Be Subject to Consumption-Based Taxation?}

reform that range between $1-2 \%$ of remaining lifetime utility. AAKSW do not analyze the effects of adding transition relief to mitigate these losses. However, they do analyze the effects of the Flat Tax, with and without transition relief in the form of allowing continued depreciation deductions on existing capital assets; they estimate that adding transition relief reduces the longrun increase in output from $4.5 \%$ to $1.9 \%$. This suggests that adding transition relief to the X-Tax would significantly reduce, and perhaps even reverse, its long run steady state welfare gains, especially since the windfall loss experienced by the elderly under the X-Tax is relatively large since they face relatively higher marginal tax rates.

Several recent papers provide additional evidence on the distributional effects of consumption tax reforms. Gentry and Hubbard (1997) note that high-income households tend to receive a larger fraction of their capital income in the form of returns to risk-taking and economic rents which, as argued above, are taxed similarly under income and consumption taxes. As a result, they argue that a move from the existing income tax to a consumption tax would be less regressive than it might appear; they estimate that accounting for this factor reduces the decline in the tax share paid by the top $5 \%$ of the net worth distribution by more than one third, relative to the assumption that a consumption tax exempts all capital income.

In addition, in a series of papers including Slemrod (this volume), Slemrod and Gordon and several co-authors have investigated the extent to which capital income is actually taxed under the existing income tax. For example, Gordon and Slemrod (1988) find that if the US had switched to an X-Tax-type regime in 1983, the aggregate change in personal and corporate income tax revenues would have been virtually zero; that is, the taxation of capital income under the income tax at that time was sufficiently ineffective - primarily due to corporate and personal interest deductions that were not offset by interest income taxation at individual level - that it raised virtually no revenue. Moreover, they also found that the burden of capital income taxation was borne primarily by lower income investors who hold a disproportionate share of taxable bonds, rather than by higher income investors, who tend to borrow heavily to invest in assets that 


\section{Should Capital Income Be Subject to Consumption-Based Taxation?}

generate more lightly taxed capital gains. 5556 Gordon, Kalambokidis and Slemrod (2004) replicated this analysis for the 1995 structure. They obtained a similar distributive pattern for capital income taxes in the lower and middle income classes, but also showed that very high income taxpayers bore a significant portion of the capital income tax burden in that year. In addition, replacing the income tax with an X-Tax-type regime would have, after adjusting for cyclical factors, cost $\$ 92$ billion in revenues, with the revenue increase relative to the analysis of 1983 data coming primarily from reduced opportunities for interest arbitrage by high income taxpayers due to lower interest rates and lower marginal tax rates, as well as the greater taxation of corporate income enacted as part of the Tax Reform Act of 1986. Gordon, Kalambokidis, Rohaly and Slemrod (forthcoming) replicate the analysis for 2004 and find that the amount of revenue from capital income taxation has declined, due primarily to the partial expensing provisions and dividend and capital gains rate cuts enacted in the 2002 and 2003 reforms, to only $\$ 63.8$ billion or less than seven percent of combined personal and corporate annual income tax revenues. 5758

A final point is that most dynamic models of consumption tax reform, such as the AK model, allow for only a single production good, and thus do not capture the economic efficiency gains that would arise from taxing investment more uniformly under a consumption tax, including especially investment in owner-occupied housing, relative to other forms of investment. Thus,

55 Indeed, McCaffery (2005) argues that wealthy individuals can largely avoid taxation over their lifetimes by following a strategy of investing in, and then holding until death, assets that generate capital gains while financing current consumption with debt.

56 See Gravelle (this volume) for a critique of this approach which concludes that it understates the extent to which capital income is taxed under the current income tax.

57 They estimate that this figure would have been $\$ 138.7$ billion if the partial expensing and dividend and capital gains tax rate reductions had not been enacted in 2002-03.

58 Gordon, Kalambokidis, Rohaly and Slemrod (forthcoming) also find that expanding prepaid savings accounts, as was proposed in 2004 and is currently being discussed, could result in a situation where the taxation of capital income loses revenue. This dramatically illustrates the point that piecemeal reforms that cobble together various elements of a consumption tax reform, but do not include all of its features including especially the elimination of interest deductibility, can be highly undesirable. In particular, the "five easy pieces" approach (Christian and Robbins, 2002) which would reduce rates (and eliminate the estate tax), allow expensing and exempt capital income from taxation at the individual level without providing for consumption-based tax treatment of interest expense, loses revenue and creates arbitrage opportunities while not gaining the advantages of consumption-based taxation in providing uniform tax treatment of all saving and investment decisions and a simplified tax system. 
they by construction do not capture some of the efficiency gains associated with providing consumption-based tax treatment of capital income. ${ }^{59}$

Although any conclusion from these various analyses is necessarily tentative, they suggest that a progressive consumption tax reform could be designed without causing huge redistributions of income across income classes, at least if the growth effects predicted by such models in fact materialize and transition relief is limited, and the reform is well-designed so as to improve economic efficiency to the maximum extent possible within the specified constraints of revenue and distributional neutrality. On the other hand, as will be discussed further below, there is still considerable uncertainty about the accuracy of the predictions of these models. Accordingly, as argued by Auerbach and Hassett (2005), it may be reasonable to err in designing a progressive consumption tax on the side of a slightly more progressive system than such models predict would be necessary to replicate current tax burdens in order to avoid unanticipated income redistributions.

\section{Additional Issues}

The literature on income and consumption taxation has considered a host of additional issues relevant to the debate. The following briefly discusses a few of these issues.

\section{The Size of Behavioral Responses}

One issue that often arises in discussions of the merits of consumption tax reform is whether the behavioral responses in the simulation models discussed above, especially of labor supply with respect to the after-tax wage rate and of savings with respect to the after-tax rate of return, are unreasonably large, given the relatively modest (although generally positive) responses typically

\footnotetext{
59 Note that such gains would not be obtained under an income tax reform - although more uniform treatment of business investment could in principle be achieved (if economic depreciation were measured accurately and the appropriate adjustments for inflation were made), a move to more comprehensive taxation of business income would exacerbate the already large tax bias favoring owner-occupied housing over other forms of investment. The net result would likely be a relatively small efficiency gain or an efficiency loss. Note also that additional efficiency gains could be obtained with reforms that would reduce the consumption distortions of the existing income tax, especially those attributable to tax preferences for fringe benefits; these potential efficiency gains are, however, could be achieved with either income or consumption tax reforms, and would face the same political obstacles in either case.
} 


\section{Should Capital Income Be Subject to Consumption-Based Taxation?}

found in the empirical literature (Engen, Gravelle and Smetters, 1997; Gravelle, 2002; Ballard, 2002; Bernheim, 2002). It is certainly true that some of the effects of consumption tax reforms predicted by simulation models are significantly larger than those that would be implied the current econometric literature. For example, using an infinite horizon econometric model of the US economy, Jorgenson and Wilcoxen (2002) estimate that the enactment of a pure flat rate national retail sales tax, with no exemptions or rebates, would result in short run increases in investment of nearly $80 \%$ and in labor supply of $30 \%$, with a long run increase in investment of roughly $16.5 \%$ and in labor supply of $15 \%$. Large, although typically more moderate, responses also characterize some lifecycle models, especially in the short run. ${ }^{60}$

The validity of this criticism, however, is mitigated by two factors. First, as noted above, much of the recent literature has adopted more conservative assumptions in both model structure (e.g., lifecycle rather than infinite horizon models, perfect foresight rather than myopic expectations, and more careful modeling of the consumption-tax-type features of the existing income tax ${ }^{61}$ ) and in parameter choices, resulting in more moderate behavioral responses, especially in the long run. Second, it is also possible that the existing econometric literature does not adequately capture the behavioral responses that would occur under fundamental tax reform. In particular, Summers (1988) argues that econometric estimates of the response of saving to changes in the after-tax rate of return do not adequately capture the human wealth effect that is central to his analysis. In addition, recent research by Prescott (2005) that examines differences in labor supply in the US and Europe suggests that long run labor supply elasticities are considerably greater than those found in the existing micro-based empirical literature (which typically utilizes data over a much shorter time period). Auerbach and Hassett (2005) note that if the AK model is modified to be consistent with Prescott's labor supply elasticity estimates, the effects of implementing a consumption tax on economic growth more than double.

60 See Gravelle (2002) for an extended discussion of this and other issues raised by the use of computable general equilibrium model to analyze the effects of consumption tax reforms.

61 The assumption of myopic expectations tends to overstate the short run responses to the enactment of the consumption tax reform because individuals and firms do not take into account in their behavioral responses the decline in the interest rate over time that occurs with capital accumulation. More careful modeling of the many consumption-tax-type features of the current hybrid income tax implies that the enactment of a consumption tax represents a smaller change from the existing system then if it were a true income tax (Engen and Gale, 1996). 


\section{Should Capital Income Be Subject to Consumption-Based Taxation?}

\section{Alternative Models of Saving}

As described above, most of the analyses used to estimate the effects of consumption tax reforms are based on the individual lifecycle model. Since this approach represents the "workhorse" model of individual behavior in neoclassical economics, this emphasis is not surprising. Nevertheless, several researchers have suggested that such models may present an incomplete picture of individual saving behavior. ${ }^{62}$

For example, Engen and Gale (1996) argue that much saving reflects a precautionary motive, as individuals attempt to protect themselves against fluctuations in earnings and an uncertain lifetime. They show that when precautionary saving is added to a standard lifecycle model, the savings responses induced by a consumption tax reform fall dramatically, since precautionary saving is relatively unresponsive to changes in after-tax rates of return. As a result, although the consumption tax reform still causes efficiency gains in their model, these gains are significantly smaller than in alternative analyses that do not consider precautionary saving, implying that the efficiency case for consumption tax reform is weaker if precautionary saving is a dominant factor in determining behavior.

A closely related issue is that some individual saving may reflect "target saving" behavior, that is, saving undertaken to meet a goal that is expressed in fixed dollar terms or as a target wealthincome ratio (including precautionary saving), an approach that is referred to as buffer stock saving (Samwick, 1998). In this case, a consumption tax reform may reduce saving, as a higher after-tax rate of return facilitates achievement of the savings target. Carroll and Samwick (1998) estimate that approximately one third of aggregate wealth can be attributed to such precautionary saving motives, which again would imply that lifecycle models overstate the savings responses that would occur with the enactment of a consumption tax reform.

Another issue is that individuals may not be free to borrow any point in their lifecycle, as assumed in most analyses, but instead may be credit constrained, especially early in life. For 


\section{Should Capital Income Be Subject to Consumption-Based Taxation?}

example, Hubbard and Judd (1986) note that the efficiency gains from a consumption tax reform are muted if there are a large number of individuals who are credit constrained, consume all their after-tax earnings, and are thus disproportionately negatively affected if they face higher wage or consumption taxes under a consumption tax reform. On the other hand, Hubbard and Judd also argue that a progressive consumption tax can address such liquidity problems by reducing tax rates on lower-income credit-constrained individuals, and that such an approach is preferable to a progressive income tax that distorts the saving decisions of other individuals. Moreover, problems with liquidity constraints can be addressed more directly with transfer programs such as the earned income tax credit, and presumably have been alleviated in recent years by easier access to credit card debt and tax-favored home equity loans.

In a related contribution, Aiyagari (1994) notes that for credit-constrained individuals, uncertainties about future income levels may also make some capital income taxation desirable. Specifically, individuals who are concerned about the prospect of future income declines at a point in time in which they are credit constrained will save too much. Accordingly, capital income taxation will be desirable to reduce the level of saving. However, since the discretionary saving of the relatively low-income individuals who are most likely to be credit constrained is currently very low, the empirical relevance of this proposition is unclear. In addition, Chamley (2001) shows that the case for capital income taxation under these circumstances is theoretically ambiguous, as it depends on the sign of the correlation between saving and the marginal utility of consumption, which is theoretically indeterminate. Finally, as suggested previously, the desirability and political feasibility of a tax policy designed explicitly to penalize savers in the current low-saving environment is open to serious question.

Another potentially serious concern is that individual saving behavior is far more erratic than that predicted by any of the models they characterize the conventional economic literature. Specifically, the relatively new field of behavioral economics has suggested a variety of new

62 Indeed, AAKSW note that in their simulations they use a relatively low value of the intertemporal elasticity of substitution, a key parameter in determining saving responsiveness, to compensate for the lack of non-life-cycle saving motives in their model. 


\section{Should Capital Income Be Subject to Consumption-Based Taxation?}

models of individual behavior that have implications for modeling individual saving behavior (Bernheim, 1997, 2002). To cite just one example, individual decisions may reflect a balancing of the desire for immediate gratification against the desire to engage in more prudent behavior by saving for the future. In this case, the existence of tax preferences for savings under the income tax imply government encouragement of saving that may successfully sway behavior away from immediate consumption, which may be reinforced by features such as restrictions and penalties on withdrawals from tax-preferred savings plans and systematic payroll deductions for savings. If such features are eliminated under a consumption tax reform, saving might actually decline. In particular, Bernheim (1997) notes that since employer-provided pensions would lose their relative tax advantage under a consumption tax reform, employers might reduce the extent of pension coverage. As a result, savings might decline because some individuals would no longer be constrained to save more than they desired or be penalized for withdrawals from savings to finance current consumption, because current matching provisions and non-discrimination requirements may result in additional saving especially among lower income individuals, and because the existence of employer-provided pension plans may heighten employee awareness of the need to save for retirement. Note, however, that these effects might be partially or even fully offset if a consumption tax reform were reasonably perceived as an even more comprehensive government encouragement of all forms of saving. It seems clear that the implications of the behavioral economics literature for fundamental tax reform merit further study.

\section{$\underline{\text { Transitional Issues }}$}

Transitional issues are often perceived to present a formidable obstacle to the enactment of a consumption tax reform. Although a wide variety of transitional problems would arise with such a reform, ${ }^{63}$ most discussions have focused on two issues. First, in the absence of transition rules, the enactment of a consumption tax reform might result in a one-time fall in equity prices. Under a value-added tax or national retail sales tax, this would most likely occur due to inflation in the form of a one-time tax-induced increase in consumer prices that would reduce the purchasing

63

63 For example, see Sarkar and Zodrow (1993), Bradford (1996), Pearlman (1996), Shaviro (2000) and Zodrow (1997, 2002). 


\section{Should Capital Income Be Subject to Consumption-Based Taxation?}

power of existing real assets. Under the direct consumption tax options, such as the Flat Tax, XTax or an expenditure tax, the relative value of existing capital would decline because remaining depreciation deductions would be denied while competing investments in new capital would be expensed; an equilibrium with equal after-tax returns on both new and old assets could occur only if the prices of old assets fell. ${ }^{64}$ Second, the enactment of the consumption tax reform might also result in a one-time decline in the price of existing owner-occupied housing, which would lose its current tax advantage relative to alternative non-housing investments, and would experience a reduction in demand due to the elimination of home mortgage interest deductions and/or deductions for property taxes. Some observers have suggested that the resulting declines in asset prices would be severe - on the order of 20-30\% (Gravelle, 1995; Cappoza, Green and Hendershott, 1996).

However, as argued by Lyon and Merrill (2001), Bruce and Holtz-Eakin (1999) and Zodrow (2002), these analyses neglect a variety of factors that would act to mitigate these asset price declines. In the case of equity prices, the most important of these factors are the costs of adjusting the capital stock in response to the enactment of reform, which imply that existing capital would earn above normal returns during the transition to a new equilibrium, and the fact that the returns to capital that reflect economic rents would be taxed similarly under both income and consumption tax regimes and thus would not raise any transitional issues. Simulation results by Auerbach (1996) and Altig, Auerbach, Kotlikoff, Smetters and Walliser (2001) suggest that adjustment costs alone play a significant role in reducing and in some cases eliminating reforminduced declines in equity values.

In the case of housing, Gravelle (1996) and Diamond and Zodrow (1999) note that any tendency toward price declines would also be mitigated by numerous factors, with the two most important being declines in interest rates and reductions in the supply of owner-occupied housing including reductions in new construction, depreciation and conversion to rental housing (which would be

64 Note that existing assets could be put on an equal footing with new assets only if all remaining basis were expensed at the time of enactment of a consumption tax reform. 
treated very generously under the new regime). Simulations by Diamond and Zodrow (2005) suggest that the declines in the price of owner-occupied housing would be on the order of 3-5\%, far smaller than those suggested above, and dissipate quickly over time.

Thus, it is far from clear that transition problems are a "show stopper" for fundamental tax reform. Note, however, that such results suggest that transition relief should be kept at a minimum during a move to a consumption tax, especially since, as discussed above, the enactment of transition rules significantly reduces the efficiency gains that can be obtained from such a reform, as well as the progressive impact of a one-time tax on existing capital (Zodrow, 2002). The relatively harsh transition rules that accompanied the enactment of the Tax Reform Act of 1986 suggest the possibility that transition relief could be limited under a consumption tax reform, as does the fact that any distributional problems associated with reform are reduced if transition relief is kept to a minimum. However, as argued by Pearlman (1996), political realities suggest that some transition rules are inevitable, and transition rules eliminate the need to create complex rules that limit attempts to avoid a one-time reform-induced transition "hit" on existing capital (Shaviro, 2000; Weisbach, 2003). If so, the costs of such transition rules should be kept to a minimum by using targeted grandfather rules (Zodrow, 1992); for example, transition relief could be limited to allowing continued depreciation allowances only on long-lived assets, especially since recent equipment purchases have benefited from bonus depreciation. In addition, transition rules could be coupled with compensating provisions; for example, under the Flat Tax or X-Tax, phased-out deductions for home mortgage interest could be accompanied by similarly phased-out taxation of the associated interest income, and expensing of new investment might be limited to a fraction of the purchase price for firms with significant continuing deductions for depreciation on existing investment (Hall and Rabushka, 1995).

\section{CONCLUSION}

The debate regarding whether capital income should be subject to consumption-based taxation has raged for many years and is likely to intensify as the United States examines various options 


\section{Should Capital Income Be Subject to Consumption-Based Taxation?}

for fundamental tax reform. What lessons can be drawn from the voluminous literature on this subject?

The theoretical literature is generally supportive of the desirability of consumption-based taxation of capital income. The strongest case is provided by the infinite horizon models, which argue that the exponentially increasing distortions of future consumption decisions associated with capital income taxation imply that in the long run the optimal tax rate on capital income is zero. A similar result can be obtained in the context of life cycle models, although in this case the results are more tenuous as they depend on assumptions regarding individual tastes that seem plausible, at least to a first approximation, but are unproven. In terms of tax fairness, consumption-based taxation is desirable on horizontal equity grounds, and a central theoretical result indicates that vertical equity goals can be achieved with only progressive direct taxes on consumption. Moreover, the relatively low level of revenues collected by the taxation of capital income under the current income tax suggests that approximating the current distribution of the tax burden is possible under a consumption tax. Although this task is facilitated by the increased importance in recent years of wage income in generating income inequality, the concern that a consumption tax, especially in the form of an indirect tax or the Flat Tax, would be significantly more regressive than the current tax system, especially at the highest income levels, pervades the debate. Consumption taxes also have the important advantage that they are inherently simpler than taxes based on income, although some of this advantage would be muted as current "pure" proposals for reform are modified to accommodate a variety of real-world complications. Indeed, one of the most critical factors in advancing the debate is the ongoing development of more fully specified proposals for consumption tax reform, with the work of David Bradford on his X-Tax setting the standard for such endeavors.

As described above, the results of large-scale computable general equilibrium models have played an important role in buttressing the case for consumption tax reform. Many of these models indicate that such a reform would generate impressive improvements in economic performance and gains in economic welfare, especially in the long run. At the same time, it is important to note that these gains are significantly muted, and in a few cases even reversed, once 


\section{Should Capital Income Be Subject to Consumption-Based Taxation?}

reform is accompanied by transition rules to protect old capital and as the progressivity of the tax system increases. This suggests that transition relief should be kept to a minimum in implementing a consumption tax reform (and the analysis above suggests several reasons why such treatment would be appropriate) and that keeping rates relatively low by eliminating tax preferences at the business level and severely limiting them at the individual level, especially at the high end of the income distribution where the gains from reform concentrated, is critical to attaining the efficiency gains from such a reform and achieving rough distributional neutrality. In addition, it is equally important to note that current models do not capture all of the potential efficiency gains from fundamental tax reform, and thus may understate the potential for such gains; items often not considered (depending on the model) include the gains attributable to an improved allocation of capital across sectors, especially across housing and non-housing production and across the corporate and non-corporate sectors, increased inflows of foreign capital, the elimination of financing distortions, and any positive externalities (e.g., on the growth rate of technological innovation) from tax-induced increases in investment (Stokely and Rebelo, 1995) - not to mention the potential gains from a well-designed and simpler tax system that would require less resources for compliance and administration and be less susceptible to avoidance and evasion.

The discussion in this paper (and the other papers in this volume) suggest two primary directions for future research that would help clarify the main issues in the ongoing debate regarding fundamental tax reform. ${ }^{65}$ The first is continued evolution of simulation models of consumption tax reforms in order to more fully capture all of their efficiency gains and distributional effects on both current and future generations, and as many of the "real world" complications of reform as possible. The second is continued development of the details of the structures of the various reform proposals, in order to understand more clearly how effectively they would cope with various real-world complications and to help in choosing among the various prototypes for reform. It is clear that the specific structures of consumption tax reforms have significant implications for their economic effects and thus their desirability that must be carefully analyzed 
for each proposal. Finally, as noted above, it is important to note that piecemeal changes in the general direction of consumption tax reform run the risk of losing revenues and creating arbitrage opportunities while falling far short of attaining all the potential gains that might be achieved with a well-designed reform package - gains that must be achieved for a consumption tax to be a desirable approach to reform.

65 See also Zodrow and Mieszkowski (2002). 


\section{Should Capital Income Be Subject to Consumption-Based Taxation?}

\section{REFERENCES}

Aaron, Henry J. and Harvey Galper, 1985. Assessing Tax Reform (Washington DC: Brookings Institution Press).

Aaron, Henry J. and William G. Gale (eds.), 1996. Economic Effects of Fundamental Tax Reform (Washington DC: Brookings Institution Press).

Aiyagari, S. Rao, 1994. "Uninsured Idiosyncratic Risk and Aggregate Saving," Quarterly Journal of Economics 109, 659-84.

Altig, David, Alan J. Auerbach, Laurence J. Kotlikoff, Kent A. Smetters, and Jan Walliser, 2001. "Simulating Fundamental Tax Reform in the United States," American Economic Review 91, 574-595.

Andrews, William D., 1974. "A Consumption-Type or Cash Flow Personal Income Tax," Harvard Law Review 87, 1113-88.

Atkinson, Anthony B. and Agnar Sandmo, 1980. "Welfare Implications of the Taxation of Savings," Economic Journal 90, 529-549.

Atkinson, Anthony B. and Joseph E. Stiglitz, 1976. "The Design of Tax Structure: Direct Versus Indirect Taxation," Journal of Public Economics 6, 55-75.

Atkinson, Anthony and Joseph E. Stiglitz, 1980. Lectures on Public Economics (New York: McGraw-Hill).

Auerbach, Alan J., 1979. "A Brief Note on a Non-existent Theorem about the Optimality of Uniform Taxation," Economic Letters 3, 49-52.

Auerbach, Alan J., 1996. “Tax Reform, Capital Allocation, Efficiency, and Growth,” in Henry J. Aaron and William G. Gale (eds.), Economic Effects of Fundamental Tax Reform (Washington DC: Brookings Institution Press), pp. 29-73.

Auerbach, Alan J., and David F. Bradford, 2004, “Generalized Cash-Flow Taxation,” Journal of Public Economics 88, 957-980.

Auerbach, Alan J. and Kevin A. Hassett, 2005. "Conclusion," in Alan J. Auerbach and Kevin A. Hassett (eds.), Toward Fundamental Tax Reform (Washington DC: AEI Press), pp. 14958.

Auerbach, Alan J. and Kevin A. Hassett, 2005a. Toward Fundamental Tax Reform (Washington DC: AEI Press). 


\section{Should Capital Income Be Subject to Consumption-Based Taxation?}

Auerbach, Alan J. and James R. Hines, 2002. "Taxation and Economic Efficiency," in Alan J. Auerbach and Martin Feldstein (eds.), Handbook of Public Economics, Volume 4 (Amsterdam: Elsevier), pp. 1347-1421.

Auerbach, Alan J. and Laurence J. Kotlikoff, 1987. Dynamic Fiscal Policy (Cambridge UK: Cambridge University Press).

Avi-Yonah, Reuven S., 2004. "Risk, Rents, and Regressivity: Why the United States Needs Both an Income Tax and a VAT," Tax Notes International 37 (December 20), 177-95.

Balcer, Yves, Irwin Garfinkel, Kathy J. Krynski and Efraim Sadka, 1983. "Income Redistribution and the Structure of Indirect Taxation," in Elhanan Helpman, Assaf Razin, and Efraim Sadka (eds.), Social Policy Evaluation: An Economic Perspective (New York: Academic Press).

Ballard, Charles L., 1990. "On the Specification of Simulation Models for Evaluating Income and Consumption Taxes," in Manfred Rose (ed.), Heidelberg Congress on Taxing Consumption (Berlin: Springer-Verlag).

Ballard, Charles L., 2002. "International Aspects of Fundamental Tax Reform," in George R. Zodrow and Peter Mieszkowski (eds.), United States Tax Reform in the 21st Century (Cambridge UK: Cambridge University Press).

Bankman, Joseph, 2004. “The Tax Shelter Problem,” National Tax Journal 57, 925-36.

Bankman, Joseph and Thomas Griffith, 1992. "Is the Debate Between an Income Tax and a Consumption Tax a Debate About Risk? Does It Matter?” Tax Law Review 47, 377-406.

Barthold, Thomas A., 1993. "How Should We Measure Distribution?" National Tax Journal 46, 291-299.

Bernheim, B. Douglas, 1997. "Taxation and Saving: A Behavioral Perspective," Proceedings of the Eighty-Ninth Annual Conference on Taxation (Washington DC: National Tax Association).

Bernheim, B. Douglas, 2002. "Taxation and Saving," in Alan J. Auerbach and Martin Feldstein (eds.), Handbook of Public Economics, Volume 3 (Amsterdam: Elsevier).

Blumenthal, Marsha and Joel Slemrod, 1995. "The Compliance Cost of Taxing Foreign-Source Income: Its Magnitude, Determinants and Policy Implications." International Tax and Public Finance 2, 37-54.

Bond, Stephen R., Michael P. Devereux and Malcolm J. Gammie, 1996. "Tax Reform to Promote Investment," Oxford Review of Economic Policy 12, 109-17.

Boskin, Michael J. (ed.), 1996. Frontiers of Tax Reform (Stanford: Hoover Institution Press). 


\section{Should Capital Income Be Subject to Consumption-Based Taxation?}

Bradford, David F. 1980. "The Case for a Personal Consumption Tax," in Joseph Pechman (ed.), What Should Be Taxed: Income or Expenditure? (Washington DC: Brookings Institution Press), pp. 77-113.

Bradford, David F., 1986. Untangling the Income Tax (Cambridge MA: Harvard University Press).

Bradford, David F., 1987. "On the Incidence of Consumption Taxes," in Charls E. Walker and Mark A. Bloomfield (eds.), The Consumption Tax: A Better Alternative (Cambridge, MA: Ballinger), pp. 243-61.

Bradford, David F., 1996. "Consumption Taxes: Some Fundamental Transition Issues," in Michael J. Boskin (ed.), Frontiers of Tax Reform (Stanford: Hoover Institution Press), pp. 123-50.

Bradford, David F., 1996a. "Treatment of Financial Services under Income and Consumption Taxes," in Henry J. Aaron and William G. Gale (eds.), Economic Effects of Fundamental Tax Reform (Washington, D.C.: Brookings Institution Press), pp. 437-60.

Bradford, David F., 2003. "Addressing the Transfer-Pricing Problem in an Origin-Basis X Tax," International Tax and Public Finance 10, 591-610.

Bradford, David F., 2005. "A Tax System for the Twenty-First Century," in Alan J. Auerbach and Kevin A. Hassett (eds.), Toward Fundamental Tax Reform (Washington DC: AEI Press), pp. 81-94.

Bruce, Donald and Douglas Holtz-Eakin, 1999. "Fundamental Tax Reform and Residential Housing," Journal of Housing Economics 8, 249-271.

Burton, David and Dan Mastromarco, 1997. "Emancipating America from the Income Tax: How a National Sales Tax Would Work," Policy Analysis No. 272 (Washington DC: Cato Institute).

Capozza, Dennis R., Richard K. Green, and Patric H. Hendershott, 1996. "Taxes, Mortgage Borrowing, and Residential Land Prices," in Henry J. Aaron and William G. Gale (eds.), Economic Effects of Fundamental Tax Reform (Washington DC: Brookings Institution Press), pp. 171-98.

Carasso, Adam, C. Eugene Steuerle, and Elizabeth Bell, 2005. "Making Tax Incentives for Homeownership More Equitable and Efficient," Urban-Brookings Tax Policy Center, Discussion Paper No. 21.

Carroll, Christopher D., 2000. Why Do the Rich Save So Much?" in Joel Slemrod (ed.), Does Atlas Shrug: The Economic Consequences of Taxing the Rich (Cambridge MA: Harvard University Press). 
Carroll, Christopher D. and Andrew A. Samwick, 1998. "How Important is Precautionary Saving?" Review of Economics and Statistics 80, 410-419.

Chamley, Christophe, 1986. "Optimal Taxation of Capital Income in General Equilibrium with Infinite Lives," Econometrica 54, 607-22.

Chamley, Christophe, 2001. "Capital Income Taxation, Wealth Distribution and Borrowing Constraints," Journal of Public Economics 79, 55-69.

Chari, V.V., Lawrence J. Christiano, and Patrick J. Kehoe, 1994. "Optimal Fiscal Policy in a Business Cycle Model,” Journal of Political Economy 102, 617-52.

Christian, Ernest and Gary Robbins, 2002. "Stealth Approach to Tax Reform," Washington Times (November 1).

Cnossen, Sijbren, 2000. "Taxing Capital Income in the Nordic Countries: A Model for the European Union?" in Sijbren Cnossen (ed.), Taxing Capital in the European Union (Oxford: Oxford University Press).

Coakley, Jerry, Farida Kulasi and Ron Smith, 1998. "The Feldstein-Horioka Puzzle and Capital Mobility: A Review," International Journal of Finance and Economics 3, 169-188.

Cremer, Helmuth, Pierre Pestieau and Jean-Charles Rochet, 2003. "Capital Income Taxation when Inherited Wealth is Not Observable, Journal of Public Economics 87: 2475-2490.

Diamond, John, Craig Johnson and George R. Zodrow, 1997. "Bequests, Saving and Taxation," Proceedings of the Eighty-Ninth Annual Conference on Taxation (Washington DC: National Tax Association).

Diamond, John W. and George R. Zodrow, 2005. "Consumption Tax Reform and Corporate Equity and Housing Prices," Manuscript, Rice University.

Driffill, E. John and Harvey Rosen, 1983. "Taxation and Excess Burden: A Life Cycle Perspective," International Economic Review 24, 671-683.

Dupor, Bill, Lance Lochner, Christopher Taber, and Mary Beth Wittekind, 1996. "Some Effects of Taxes on Schooling and Training," American Economic Review, Papers and Proceedings 86, 340-346.

Eaton, Jonathan and Harvey Rose, 1980. Taxation, Human Capital and Uncertainty," American Economic Review 70,705-715.

Engen, Eric M. and William G. Gale, 1996. "The Effects of Fundamental Tax Reform on Saving," in Henry J. Aaron and William G. Gale (eds.), Economic Effects of Fundamental Tax Reform (Washington DC: Brookings Institution Press), pp. 83-112. 
Engen, Eric M., Jane Gravelle, and Kent Smetters, 1997. "Dynamic Tax Models: Why They Do the Things They Do," National Tax Journal 50, 657-82.

Erosa, Andres and Martin Gervais, 2002. “Optimal Taxation in Life-Cycle Economies,” Journal of Economic Theory 105, 338-69.

Evans, Owen J., 1983. "Tax Policy, the Interest Elasticity of Saving, and Capital Accumulation: Numerical Analysis of Theoretical Models," American Economic Review 73, 398-410.

Feenberg, Daniel R., Andrew W. Mitrusi, and James M. Poterba, 1997. "Distributional Effects of Adopting a National Retail Sales Tax," in James M. Poterba (ed.), Tax Policy and the Economy, Volume 11 (Cambridge MA: MIT Press), pp. 49-89.

Feld, Alan L., 1995. "Living with the Flat Tax," National Tax Journal 48 (4, December): 603-17.

Feldstein, Martin, 1978. "The Welfare Cost of Capital Income Taxation," Journal of Political Economy 86, 29-51.

Feldstein, Martin and Charles Horioka, 1980. "Domestic Savings and International Capital Flows," Economic Journal 90, 314-29.

Feldstein, Martin and Phillipe Bacchetta, 1991. "National Saving and International Investment," in B. Douglas Bernheim and John B. Shoven (eds.), National Saving and Economic Performance (Chicago: University of Chicago Press), pp. 201-20.

French, Kenneth R. and James M. Poterba, 1993. "Investor Diversification and International Equity Markets," in Richard Thaler (ed.), Advances in Behavioral Finance (New York: Russell Sage Foundation).

Fullerton, Don and Diane Lim Rogers, 1993. Who Bears the Lifetime Tax Burden? (Washington DC: Brookings Institution Press).

Fullerton, Don and Diane Lim Rogers, 1996. "Lifetime Effects of Fundamental Tax Reform," in Henry J. Aaron and William G. Gale (eds.), Economic Effects of Fundamental Tax Reform (Washington DC: Brookings Institution Press), pp. 321-47.

Gale, William G., 2005. "Tax Reform Options in the Real World," in Alan J. Auerbach and Kevin A. Hassett (eds.), Toward Fundamental Tax Reform (Washington DC: AEI Press), pp. 34-47.

Gale, William G. and Janet Holtzblatt, 2002. "The Role of Administrative Issues in Tax Reform: Simplicity, Compliance and Administration," in George R. Zodrow and Peter Mieszkowski (eds.), United States Tax Reform in the 21st Century (Cambridge UK: Cambridge University Press). 


\section{Should Capital Income Be Subject to Consumption-Based Taxation?}

Gale, William G. and Joel Slemrod, 2001. Rethinking Estate and Gift Taxation (Washington DC: Brookings Institution Press).

Garriga, Carlos, 2003. "Optimal Fiscal Policy in Overlapping Generations Models,” Manuscript, Florida State University.

Gentry, William M. and R. Glenn Hubbard, 1997. "Distributional Implications of Introducing a Broad-Based Consumption Tax," in James M. Poterba (ed.), Tax Policy and the Economy, Volume 11 (Cambridge MA: MIT Press).

Gillis, Malcolm, Peter Mieszkowski, and George R. Zodrow, 1996. "Indirect Consumption Taxes: Common Issues and Differences Among the Alternative Approaches," Tax Law Review 51 (Summer): 725-74.

Ginsburg, Martin D., 1995. "Life Under a Personal Consumption Tax: Some Thoughts on Working, Saving, and Consuming in Nunn-Domenici's Tax World," National Tax Journal 68, 585-602.

Gordon, Roger H., 1986. "Taxation of Investment and Savings in the World Economy," American Economic Review 76, 1086-1102.

Gordon, Roger H., 1992. “Can Capital Income Taxes Survive in Open Economies? Journal of Finance 47, 1159-80.

Gordon, Roger H., 2000. "Taxation of Capital Income vs. Labour Income: An Overview," in Sijbren Cnossen (ed.), Taxing Capital in the European Union (Oxford: Oxford University Press).

Gordon, Roger H. and James R. Hines Jr., 2002. "International Taxation," in Alan J. Auerbach and Martin Feldstein (eds.), Handbook of Public Economics Volume 4 (Amsterdam: Elsevier), pp. 1935-96.

Gordon, Roger H. and Joel Slemrod, 1988. "Do We Collect Any Revenue from Taxing Capital Income?" in Lawrence H. Summers (ed.), Tax Policy and the Economy, Vol. 2 (Cambridge: National Bureau of Economic Research), pp. 89-130.

Gordon, Roger H., Laura Kalambokidis and Joel Slemrod, 2004. "Do We Now Collect Any Revenue from Taxing Capital Income?” Journal of Public Economics 88, 981-1009.

Gordon, Roger H., Laura Kalambokidis, Jeffrey Rohaly and Joel Slemrod, forthcoming. "Toward a Consumption Tax and Beyond," American Economic Review, Papers and Proceedings.

Goulder, Lawrence H., John B. Shoven, and John Whalley, 1983. "Domestic Tax Policy and the Foreign Sector: The Importance of Alternative Foreign Sector Formulations to Results from a General Equilibrium Tax Analysis Model," in Martin Feldstein (ed.), Behavioral 
Simulation Methods in Tax Policy Analysis (Chicago: University of Chicago Press), pp. $333-368$.

Graetz, Michael J., 2005. "A Fair and Balanced Tax System for the Twenty-First Century," in Alan J. Auerbach and Kevin A. Hassett (eds.), Toward Fundamental Tax Reform (Washington DC: AEI Press), pp. 48-69.

Gravelle, Jane G., 1994. The Economic Effects of Taxing Capital Income (Cambridge: MIT Press).

Gravelle, Jane G., 1995. "The Flat Tax and Other Proposals: Who Will Bear the Tax Burden?" Congressional Research Service Report for Congress Number 95-1141E, Washington, D.C.: U.S. Library of Congress (November 29).

Gravelle, Jane G., 1996. "The Flat Tax and Other Proposals: Effects on Housing,” Congressional Research Service Report for Congress Number 96-379E, Washington DC: U.S. Library of Congress (April 29).

Gravelle, Jane G., 2002. "Behavioral Responses to a Consumption Tax," in George R. Zodrow and Peter Mieszkowski (eds.), United States Tax Reform in the 21st Century (Cambridge UK: Cambridge University Press).

Gravelle, Jane G. and Kent Smetters, 2001. "Who Bears the Burden of the Corporate Tax in the Open Economy," Manuscript.

Grubert, Harry and John Mutti, 1985. "The Taxation of Capital Income in an Open Economy: The Importance of Resident-Nonresident Tax Treatment," Journal of Public Economics 27, 291-309.

Hall, Robert E., 2005. "Guidelines for Tax Reform: The Simple, Progressive Value-Added Consumption Tax," in Alan J. Auerbach and Kevin A. Hassett (eds.), Toward Fundamental Tax Reform (Washington DC: AEI Press), pp. 70-80.

Hall, Robert E. and Alvin Rabushka, 1983. Low Tax, Simple Tax, Flat Tax (New York: McGraw-Hill).

Hall, Robert E. and Alvin Rabushka, 1995. The Flat Tax (Stanford: Hoover Institution Press).

Harberger, Arnold C., 1995. "The ABCs of Corporate Tax Incidence: Insights Into the OpenEconomy Case," in American Council for Capital Formation (ed.), Tax Policy and Economic Growth (Washington DC: ACCF Center for Policy Research).

Hubbard, R. Glenn, 2002. "Capital Income Taxation in Tax Reform: Implications for Analysis of Distribution and Efficiency," in George R. Zodrow and Peter Mieszkowski (eds.), United States Tax Reform in the 21st Century (Cambridge UK: Cambridge University Press). 


\section{Should Capital Income Be Subject to Consumption-Based Taxation?}

Hubbard, R. Glenn, 2005. "Economic Effects of the 2003 Partial Integration Proposal in the United States," International Tax and Public Finance 12, 97-108.

Hubbard, R. Glenn, 2005a. "Would a Consumption Tax Favor the Rich?" in Alan J. Auerbach and Kevin A. Hassett (eds.), Toward Fundamental Tax Reform (Washington DC: AEI Press), pp. 81-94.

Hubbard, R. Glenn and Kenneth L. Judd, 1986. "Liquidity Constraints, Fiscal Policy, and Consumption," Brookings Papers on Economic Activity (1): 1-50.

Institute for Fiscal Studies (Meade Commission), 1978. The Structure and Reform of Direct Taxation (London: George Allen \& Unwin).

Jones, Larry E., Rodolfo E. Manuelli, and Peter E. Rossi, 1993. “Optimal Taxation in Models of Endogenous Growth,” Journal of Political Economy 101, 485-517.

Jorgenson, Dale W. and Peter J. Wilcoxen, 2002. "The Economic Impact of Fundamental Tax Reform," in George R. Zodrow and Peter Mieszkowski (eds.), United States Tax Reform in the 21st Century (Cambridge UK, Cambridge University Press).

Judd, Kenneth L., 1985. "Redistributive Income in a Simple Perfect Foresight Model," Journal of Public Economics 28, 59-83.

Judd, Kenneth L., 1997. "The Optimal Tax Rate for Capital Income is Negative," NBER Working Paper No. 6004 (Cambridge: National Bureau of Economic Research).

Judd, Kenneth L., 1998. "Taxes, Uncertainty, and Human Capital," American Economic Review 88, 289-292.

Judd, Kenneth L., 1999. "Optimal Taxation and Spending in General Competitive Growth Models," Journal of Public Economics 71, 1-26.

Judd, Kenneth L., 2001. "The Impact of Tax Reform in Modern Dynamic Economies," in K. Hassett and G. Hubbard (eds.), Transition Costs of Fundamental Tax Reform (Washington DC: AEI Press), pp. 5-53.

Kaplow, Louis, 2004. "On the Undesirability of Commodity Taxation Even When Income Taxation is Not Optimal," John M. Olin Center for Law and Economics, Discussion Paper No. 470.

King, Mervyn A., 1980. "Savings and Taxation," in G. A. Hughes and G. M. Heal (eds.), Public Policy and the Tax System (London: Allen and Unwin), pp. 1-35.

Kotlikoff, Laurence J., 1996. "Saving and Consumption Taxation: The Federal Retail Sales Tax Example," in Michael J. Boskin (ed.), Frontiers of Tax Reform (Stanford: Hoover Institution Press), pp. 160-180. 


\section{Should Capital Income Be Subject to Consumption-Based Taxation?}

Kotlikoff, Laurence J., 1998. “The A-K Model - It's Past, Present, and Future,” Working Paper 6684 (Cambridge, MA: National Bureau of Economic Research).

Lawrence, Emily C., 1991. "Poverty and the Rate of Time Preference: Evidence from Panel Data," Journal of Political Economy 99 (1, February): 54-77.

Lucas, Robert E. Jr., 1990. "Supply-Side Economics: An Analytical Review," Oxford Economic Papers 42, 293-316.

Lyon, Andrew B. and Peter R. Merrill, 2001. "Asset Price Effects of Fundamental Tax Reform," in Kevin A. Hassett and R. Glenn Hubbard (eds.), Transition Costs of Fundamental Tax Reform (Washington DC: AEI Press), pp. 58-91.

McCaffery, Edward J., 2005. “A New Understanding of Tax," Michigan Law Review 103, 807938.

McLure, Charles E. Jr., 1987. The Value-Added Tax: Key to Deficit Reduction? (Washington DC: AEI Press).

McLure, Charles E. Jr. and George R. Zodrow, 1996. "A Hybrid Approach to the Direct Taxation of Consumption," in Michael J. Boskin (ed.), Frontiers of Tax Reform (Stanford: Hoover Institution Press), pp. 70-90.

McLure, Charles E. Jr., Jack Mutti, Victor Thuronyi, and George R. Zodrow, 1990. The Taxation of Income from Business and Capital in Colombia: Fiscal Reform in the Developing World (Durham NC: Duke University Press).

Mieszkowski, Peter and Michael G. Palumbo, 2002. "Distributive Analysis of Fundamental Tax Reform," in George R. Zodrow and Peter Mieszkowski (eds.), United States Tax Reform in the 21st Century (Cambridge UK: Cambridge University Press).

Milesi-Ferretti, Gian M. and Nouriel Roubini, 1998. "On the Taxation of Human and Physical Capital in Models of Endogenous Growth," Journal of Public Economics 70, 237-54.

Murray, Matthew N., 1997. "Would Tax Evasion and Tax Avoidance Undermine a National Retail Sales Tax?” National Tax Journal 50, 167-82.

Naito, Hisahiro, 1999. "Re-Examination of Uniform Commodity Taxes under a Non-Linear Income Tax System and its Implication for Production Efficiency," Journal of Public Economics 71, 165-88.

Nerlove, Marc, 1972. "On Tuition and the Costs of Higher Education: Prolegomena to Conceptual Framework," Journal of Political Economy 80, 178-218.

Nielsen, Soren Bo and Peter Birch Sorensen, 1994. "On the Optimality of the Nordic System of Dual Income Taxation, Journal of Public Economics 63, 311-329. 


\section{Should Capital Income Be Subject to Consumption-Based Taxation?}

Pearlman, Ronald A., 1996. "Transition Issues in Moving to a Consumption Tax: A Tax Lawyer's Perspective," in Henry J. Aaron and William G. Gale (eds.), Economic Effects of Fundamental Tax Reform (Washington DC: Brookings Institution Press), pp. 393-427.

Piketty, Thomas and Emmanuel Saez, 2003. "Income Inequality in the United States, 19131998," Quarterly Journal of Economics 118, 1-39. (Data updated to 2002 at http://emlab.berkeley.edu/users/saez/)

Prescott, Edward C., 2005. "The Elasticity of Labor Supply and the Consequences for Tax Policy," in Alan J. Auerbach and Kevin A. Hassett (eds.), Toward Fundamental Tax Reform (Washington DC: AEI Press), pp. 123-34.

Razin, Assaf and Efraim Sadka, 1991. "International Tax Competition and Gains from Tax Harmonization," Economics Letters 37, 69-76.

Roubini, Nouriel and Gian Milesi-Ferretti, 1998. "On the Taxation of Human and Physical Capital in Models of Endogenous Growth," Journal of Public Economics 70: 237-254.

Saez, Emmanuel, 2002. "The Desirability of Commodity Taxation under Non-Linear Income Taxation and Heterogeneous Tastes," Journal of Public Economics 83, 217-30.

Saez, Emmanuel, 2002a. "Optimal Progressive Capital Income Taxes in the Infinite Horizon Model," Working Paper 9046 (Cambridge, MA: National Bureau of Economic Research).

Saez, Emmanuel, 2004. "Direct or Indirect Tax Instruments for Redistribution: Short-Run versus Long-Run," Journal of Public Economics 88, 503-18.

Samwick, Andrew A., 1998. “Tax Reform and Target Saving,” National Tax Journal 51, 621-35.

Sarkar, Shounak and George R. Zodrow, 1993. "Transitional Issues in Moving to a Direct Consumption Tax," National Tax Journal 46, 359-76.

Seidman, Laurence S., 1983. "Taxes in a Life Cycle Growth Model with Bequests and Inheritances," American Economic Review 73, 437-41.

Shakow, David J., 1986. "Taxation without Realization: A Proposal for Accrual Taxation," University of Pennsylvania Law Review **

Shaviro, Daniel, 2000. When Rules Change: An Economic and Political Analysis of Transition Relief and Retroactivity (Chicago: University of Chicago Press).

Shaviro, Daniel, 2004. "Replacing the Income Tax with a Progressive Consumption Tax," Tax Notes 102 (April 5), 91-162. 


\section{Should Capital Income Be Subject to Consumption-Based Taxation?}

Slemrod, Joel, 1996. "Which Is the Simplest Tax System of Them All?" in Henry J. Aaron and William G. Gale (eds.), Economic Effects of Fundamental Tax Reform (Washington DC: Brookings Institution Press), pp. 355-84.

Slemrod, Joel, 2005. "My Beautiful Tax Reform," in Alan J. Auerbach and Kevin A. Hassett (eds.), Toward Fundamental Tax Reform (Washington DC: AEI Press), pp. 135-48.

Sorensen, Peter Birch, 1994. "From a Global Income Tax to the Dual Income Tax: Recent Reforms in the Nordic Countries," International Tax and Public Finance 1, 57-79.

Starrett, David A., 1988. "Effects of Taxes on Saving," in Henry J. Aaron, Harvey Galper, and Joseph Pechman (eds.), Uneasy Compromise: Problems of a Hybrid IncomeConsumption Tax (Washington DC: Brookings Institution).

Steuerle, Eugene C., 2004. Contemporary U.S. Tax Policy (Washington DC: Urban Institute Press).

Stiglitz, Joseph E., 1982. "Self-Selection and Pareto Efficient Taxation," Journal of Public Economics 17, 213-40.

Stokey, Nancy L. and Sergio Rebelo, 1995. "Growth Effects of Flat-Rate Taxes," Journal of Political Economy 103, 519-550.

Summers, Lawrence H., 1981. "Capital Taxation and Accumulation in a Life Cycle Growth Model," American Economic Review 74, 533-44.

Summers, Lawrence H., 1988. "Comment" in Henry J. Aaron, Harvey Galper, and Joseph A. Pechman (eds.), Uneasy Compromise: Problems of a Hybrid Income-Consumption Tax (Washington DC: The Brookings Institution).

Taber, Christopher, 2002. "Tax Reform and Human Capital Accumulation: Evidence from an Empirical General Equilibrium Model of Skill Formation," Advances in Economic Analysis \& Policy 2, 1-36.

U.S. Department of the Treasury, 1977. Blueprints for Basic Tax Reform (Washington DC: U.S. Government Printing Office). Also available as Bradford, David F. and the U.S. Treasury Tax Policy Staff, 1984. Blueprints for Basic Tax Reform (Arlington: Tax Analysts).

U.S. Department of the Treasury, 1992. Integration of the Individual and Corporate Tax Systems: Taxing Business Income Once (Washington DC: U.S. Government Printing Office).

Varian, Hal, 1980. "Redistributive Taxation as Social Insurance," Journal of Public Economics 14, 49-68. 
Weidenbaum, Murray, 1996. "The Nunn-Domenici USA Tax: Analysis and Comparisons," in Michael J. Boskin (ed.), Frontiers of Tax Reform (Stanford: Hoover Institution Press), pp. 54-69.

Weisbach, David A., 2000. “Ironing Out the Flat Tax,” Stanford Law Review 52, 599-664.

Weisbach, David A., 2003. "Fundamental Tax Reform: Does the X-Tax Mark the Spot?" SMU Law Review 56, 201-238.

Weisbach, David A., 2004. "The Non-Taxation of Risk," New York University Tax Review 58, 157.

Weisbach, David A. and Joseph Bankman, 2005. "The Superiority of a Consumption Tax Over an Income Tax," Manuscript, University of Chicago Law School and Stanford Law School.

Zodrow, George R., 1992. "Grandfather Rules and the Theory of Optimal Tax Reform," Journal of Public Economics 49, 163-90.

Zodrow, George R., 1997. "On the Transition to Indirect or Direct Consumption-Based Taxation," in Richard Krever (ed.), Tax Conversations: A Guide to the Key Issues in the Tax Reform Debate. Essays in Honour of John G. Head (London: Kluwer Law International), pp. 27-59.

Zodrow, George R., 2002. "Transitional Issues in the Implementation of a Flat Tax or a National Retail Sales Tax," in George R. Zodrow and Peter Mieszkowski (eds.), United States Tax Reform in the 21st Century (Cambridge UK: Cambridge University Press).

Zodrow, George R., 2003. "Tax Competition and Tax Coordination in the European Union," International Tax and Public Finance 10, 651-71.

Zodrow, George R., 2005. "Capital Mobility and Source-Based Taxation of Capital Income in Small Open Economies," International Tax and Public Finance.

Zodrow, George R. and Charles E. Jr. McLure, 1991. "Implementing Direct Consumption Taxes in Developing Countries," Tax Law Review 46 (Summer): 407-87.

Zodrow George R. and Peter Mieszkowski, 2002. "The Fundamental Question in Fundamental Tax Reform," in George R. Zodrow and Peter Mieszkowski (eds.), United States Tax Reform in the 21st Century (Cambridge UK: Cambridge University Press).

Zodrow, George R. and Peter Mieszkowski (eds.), 2002a. United States Tax Reform in the 21st Century (Cambridge UK: Cambridge University Press). 